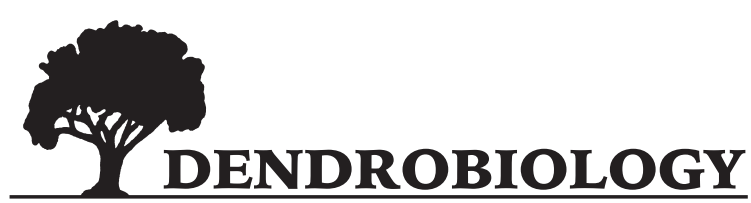

2018, vol. 79, 61-76

http://dx.doi.org/10.12657/denbio.079.006

\author{
Stanislav Vacek, Zdeněk Vacek*, Ivana Kalousková, Jan Cukor, \\ Lukáš Bílek, W. Keith Moser, Daniel Bulušek, Vilém Podrázský, \\ David Řeháček
}

\section{Sycamore maple (Acer pseudoplatanus L.) stands on former agricultural land in the Sudetes - evaluation of ecological value and production potential}

Received: 6 July 2017; Accepted: 27 November 2017

\begin{abstract}
Sycamore maple (Acer pseudoplatanus L.) is a fast-growing tree species that produces economically attractive timber, provides ecological services and has high site adaptability, but it is only a minor component of European forests. This paper describes production, structure and diversity of sycamore-dominated forest stands that originated by succession on former agricultural lands in the Orlicke hory Mts., the Czech Republic. The partial objectives were to determine impact of climatic factors on the radial growth of sycamore maple and evaluate the effect of game on natural regeneration. The number of sycamore seeds on the ground was on average 9-34 seeds $\mathrm{m}^{-2}$ and seedling mortality reached on average $89 \%$ caused by damage of hare and drought. Density of natural regeneration ranged from 1,532 to 4,244 recruits ha ${ }^{-1}$, but growth dynamic was strongly influenced by ungulate browsing $(69 \%)$ with the largest losses in sycamore (96\%). Analyses of climatic effects showed a significantly close relationship with growth of sycamore in submontane areas, being especially sensitive to extremely dry and cold winters or very high summer temperatures. Radial growth was more significantly influenced by monthly temperatures compared to precipitation, but increasing sum of annual precipitation was main positive driver factor of diameter increment. Radial growth had the strongest relationship with weather conditions in July and October of previous year and March of the current year. Stand volume ranged from 378 to $545 \mathrm{~m}^{3} \mathrm{ha}^{-1}$ at age around 75 years, while sycamore accounted for $32-82 \%$. The horizontal structure of the tree layer was mostly random to aggregated; resembling the clumped spatial pattern of natural regeneration. Besides their wood production, these stands fulfil many ecosystem functions that are associated with high ecological stability, high structural differentiation and medium to high species diversity.
\end{abstract}

Keywords: stand structure, growth dynamics, production, climate, tree-ring analysis, game damage, Central Europe

Addresses: S. Vacek, Z. Vacek, J. Cukor, L. Bílek, D. Bulušek, V. Podrázský, Czech University of Life Sciences Prague, Faculty of Forestry and Wood Sciences, Department of Silviculture, Kamýcká 129, 165 21 Prague, Czech Republic, e-mail: vacekz@fld.czu.cz

I. Kalousková, University of Hradec Králové, Faculty of Science, Rokitanského 62, 50003 Hradec Králové, Czech Republic

W. K. Moser, USDA, Forest Service, Rocky Mountain Research Station, Flagstaff, AZ, USA

D. Řeháček, Research Institute for Soil and Water Conservation, Žabovřeská 250, 15627 Prague 5

Zbraslav, Czech Republic 


\section{Introduction}

Sycamore maple (Acer pseudoplatanus L.) is a fast-growing broadleaved tree species of many European forests, especially typical for forests in central Europe (Úradníček et al., 2001). Despite its potential economic and ecological importance (Spiecker et al., 2009), the share of sycamore maple usually does not exceed 3\% according to most national inventories in Europe (Hein, 2009). This lower stand volume is caused by the fact that sycamore rarely forms pure forest stands (Jones, 1945; Hein et al., 2009). Rather, it is found in mixture with European beech (Fagus sylvatica L.), European ash (Fraxinus excelsior L.), sessile oak (Quercus petraea [Matt.] Liebl.) and Norway maple (Acer platanoides L.); to a lesser extent it is associated with English oak (Quercus robur L.), field maple (Acer campestre L.), European hornbeam (Carpinus betulus L.) and wild cherry (Prunus avium L.; Ammer, 1996; Piovesan et al., 2005; Walentowski et al., 2006; Hein et al., 2009).

Sycamore is a tree that requires high levels of soil moisture and atmospheric humidity (Úradníček et al., 2001) and can be found in a variety of different habitat conditions (Piovesan et al., 2005). Generally, sycamore is a tree species of the moist mountain oceanic climate (Ellenberg, 1996). Typical mountain habitats of sycamore are characterized by high precipitation (900 - $1400 \mathrm{~mm} \mathrm{yr}^{-1}$ ) or are located in areas where there is high atmospheric humidity, such as deep valleys and north-facing slopes (Piovesan et al., 2005). It grows most frequently on deep, humic moist soils with a high skeleton content but it does not tolerate water-logging with stagnant water. In limestone areas it occurs at the base of rocks on debris that is rich in humus deposits and sufficiently moist. The species has expanded throughout Europe, and it has been introduced into Asia, North America, South America, Australia, New Zealand and India (Röhrig \& Ulrich, 1991; Rusanen \& Myking, 2003; Kölling, 2007; Hein et al., 2009; Weidema \& Buchwald, 2010).

The sycamore growth is highly influenced by environmental conditions (Skovsgaard \& Jørgensen, 2004). Its growth is fast until 20-25 years of age, reaching about $20 \mathrm{~m}$ of height in suitable habitats and then its growth slows down (Claessens et al., 1999; Gill, 1992; Kupferschmid \& Bugmann, 2008). In these habitats sycamore exceeds in productivity European beech and European ash (Henriksen \& Bryndum, 1989; Schober, 1995; Lockow, 2004).

In most countries of Europe (Austria, Belgium, Denmark, Czech Republic, France, Germany, Lithuania, Netherlands, Poland, Sweden) sycamore has good natural regeneration (Dobrowolska, 1998; Tillisch, 2001; Rusanen \& Myking, 2003; Ambrazevicius, 2016), producing seed every year starting around the age of 25 to 30 years (Burschel \& Huss, 1997). Individual trees can produce up to 170,000 seeds that are easily carried by wind, mostly within $200 \mathrm{~m}$ distance of the parent tree (Rusanen \& Myking, 2003; Hérault et al., 2004; Thies et al., 2009). Seedlings are very vulnerable to competitive herbs (Diaci, 2002; Modrý et al., 2004; Vandenberghe et al., 2007). At young age, sycamore is very tolerant to shade; after it reaches a height of 2 to $3 \mathrm{~m}$ its requirements for light increase (Hölscher, 2004; Kazda et al., 2004). In maturity it can bear full illumination (Úradníček et al., 2001). In a number of European countries (Austria, Czech Republic, France, Germany, Switzerland, Slovakia) sycamore is heavily browsed by deer (Senn \& Suter, 2003; Modrý, et al. 2004; Weidema \& Buchwald, 2010; Vacek et al., 2014; Konôpka \& Pajtík, 2015). Compared to its co-occurring species, its competitive advantage is its easy and abundant natural regeneration and fast growth in the first years. With sufficient light, it is capable to dominate European beech, whereas in low light conditions, its mortality is markedly higher than that of European beech (Petritan et al., 2007).

Sycamore produces very valuable wood with multiple uses (Soulères, 1997; Nunez-Regueira et al., 1997). Sycamore increases biodiversity and ecological stability of forest ecosystems (Binggeli, 1993; Pommerening, 1997; Bell, 2009) and it is an important soil-improving tree species that enhances humus formation and nutrient cycling (Weber et al., 1993; Heitz \& Rehfuess, 1999). It has the potential to respond to projected future climate change (Kölling, 2007; Hein et al., 2009). For these reasons, especially in Central Europe, the species has value for both the forest sector and the wood processing industry (Spiecker et al., 2009; Thies et al., 2009).

In order to consider silvicultural practices in the face of projected global climate change and the increasing demand for ecosystem services (Spiecker et al., 2004; Puettmann \& Ammer, 2007; Foster et al., 2010; Barbati et al., 2014), it is necessary to thoroughly understand the dynamics and adaptability of forest ecosystems (Lindenmayer et al., 2000; Baycheva et al., 2013). Only then is it possible to successfully adapt the methods of sustainable and near-natural management of forest ecosystems to future changing climate (Hein et al., 2009; Coote et al., 2012; Oxbrough et al., 2014). Most of the existing silvicultural practices applied to sycamore are based on operational experience in specific environmental conditions (Kerr \& Evans, 1993; Joyce et al., 1998). Few of them are based on designed research and synthesis of acquired knowledge (Hein \& Spiecker, 2009; Sjöstedt, 2012; Straigyte \& Baliuckas, 2015). For these reasons the general objective of the present study was to describe structure and function of sycamore stands as basis for such knowledge-based 
decision making. Particular goals were to: 1) evaluate stand production, structure, biodiversity and natural regeneration with emphasis on seeds characteristic of sycamore stands originated by succession on former agricultural lands; 2) assess the impact of climatic factors (temperature, precipitation) on the radial increment of sycamore and its dynamics and 3) determine the effect of game on growth and species composition of natural regeneration.

\section{Material and Methods}

\section{Description of the study area}

The study was conducted in four forest stands with dominant sycamore maple that originated by succession on former agricultural lands in the Orlické hory Mts. Protected Landscape Area (PLA), the Czech Republic (Fig. 1). The predominant soil types are Cambisols. The average annual temperatures are between 4 and $7^{\circ} \mathrm{C}$, and precipitation ranges from 800 to $1300 \mathrm{~mm} \mathrm{y}^{-1}$ (Vacek, 2003). The study territory belongs to humid continental climate characterised by hot and humid summers and cold to severely cold winters (Dfb) according to Köppen climate classification (Köppen, 1936), respectively by detailed region Quitt distribution (Quitt, 1971) to a cold climatic region and $\mathrm{CH} 7$ subregion.

Historically, study forests were converted into pastures with only few scattered trees providing shade for cattle during the $16^{\text {th }}$ century (Roček, 1970). During the WW II pasture intensity decreased and in many localities natural succession started (Vacek et al., 2009). Important prerequisite for the recolonization by woody species was the presence of scattered seed trees and very low game stocks. Later, all study forests were left for spontaneous development without any additional silvicultural treatments. Only

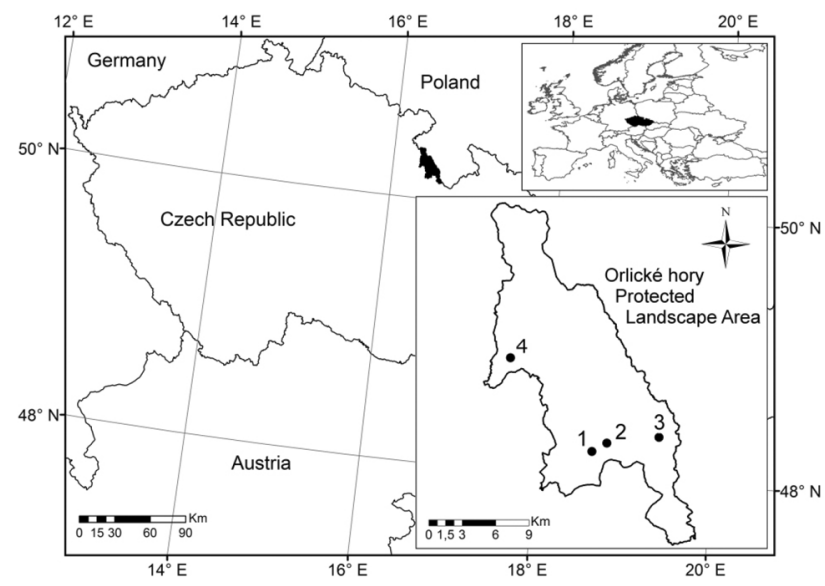

Fig. 1. Location of the permanent research plots with sycamore maple dominated forest stands in the Orlické hory Mts.

from 1992 to 1999 sanitary felling was performed. The permanent research plots (PRP) have had the same silvicultural treatment and origin according to available historical information and older forest management plants. The basic characteristics of PRP are shown in Tab. 1. A more detailed description of the area of interest can be found in Vacek et al. (2003, 2015, 2017).

In terms of phytocoenology these are mostly subalpine sycamore-beech forests, the association AceriFagetum J. et M. Bartsch 1940 and partly on PRP 1 and 2 the association Daphno mezerei-Aceretum pseudoplatani Jeník et al. 1980. On PRP there were found 29-38 species of vascular plants and 11-16 species of bryophytes. Dominant species in tree layer are Acer pseudoplatanus and Fagus sylvatica; on all herbs there are relatively prominent levels of Athyrium distentifolium, Athyrium filix-femina, Dryopteris filixmas, Oxalis acetosella, Stellaria nemorum and Dryopteris carthusiana or Polytrichum formosum and Plagiothecium curvifolium in moss layer.

Table 1. Summary of basic site characteristics of the permanent research plots

\begin{tabular}{|c|c|c|c|c|c|c|c|c|c|c|c|c|c|}
\hline ID & Plot name & $\begin{array}{c}\text { GPS } \\
\text { coordinates }\end{array}$ & $\begin{array}{l}\text { Altitude } \\
\text { (m) }\end{array}$ & $\begin{array}{l}\text { Grow. } \\
\text { season } \\
\text { (days) }\end{array}$ & $\begin{array}{l}\text { Temp. in } \\
\mathrm{GS}^{1}\left({ }^{\circ} \mathrm{C}\right)\end{array}$ & $\begin{array}{c}\text { Rainfall } \\
\text { in GS } \\
(\mathrm{mm})\end{array}$ & $\begin{array}{l}\text { Geo- } \\
\text { logy }\end{array}$ & Soil type & $\begin{array}{l}\text { Expo- } \\
\text { sure }\end{array}$ & $\begin{array}{c}\text { Slope } \\
\left({ }^{\circ}\right)\end{array}$ & $\begin{array}{c}\text { Herbal } \\
\text { cover }(\%)\end{array}$ & $\begin{array}{l}\text { Forest } \\
\text { type }^{2}\end{array}$ & Species $^{3}$ \\
\hline 1 & $\begin{array}{c}\text { Rokytnice } \\
1\end{array}$ & $\begin{array}{l}50^{\circ} 11^{\prime} 02^{\prime \prime} \mathrm{N} \\
16^{\circ} 27^{\prime} 06^{\prime \prime} \mathrm{E}\end{array}$ & 605 & 130 & 12.9 & 547 & Schist & $\begin{array}{c}\text { modal } \\
\text { Cambisol }\end{array}$ & NW & 15 & 70 & $\begin{array}{l}5 \mathrm{~F} \\
(5 \mathrm{~A})\end{array}$ & $\begin{array}{c}\text { AP, FS, FE, } \\
\text { AN, AI, } \\
\text { SA, PA }\end{array}$ \\
\hline 2 & $\begin{array}{c}\text { Rokytnice } \\
2\end{array}$ & $\begin{array}{l}50^{\circ} 11^{\prime} 05^{\prime \prime} \mathrm{N} \\
16^{\circ} 27^{\prime} 09^{\prime \prime} \mathrm{E}\end{array}$ & 595 & 130 & 12.9 & 547 & Schist & $\begin{array}{l}\text { gleyed } \\
\text { Cambisol }\end{array}$ & NW & 16 & 75 & $\begin{array}{l}5 \mathrm{~F} \\
(5 \mathrm{~A})\end{array}$ & $\begin{array}{c}\text { AP, FS, FE, } \\
\text { AN, AI, } \\
\text { BA, PA }\end{array}$ \\
\hline 3 & Uhřínov & $\begin{array}{l}50^{\circ} 12^{\prime} 22^{\prime \prime} \mathrm{N} \\
16^{\circ} 32^{\prime} 23^{\prime \prime}\end{array}$ & 725 & 115 & 10.7 & 620 & Gneiss & $\begin{array}{c}\text { lithic } \\
\text { Cambisol }\end{array}$ & $\mathrm{NE}$ & 12 & 65 & $6 \mathrm{~A}$ & $\begin{array}{c}\text { AP, FS, SA, } \\
\text { PA, AA }\end{array}$ \\
\hline 4 & $\begin{array}{l}\text { Vysoký } \\
\text { kořen }\end{array}$ & $\begin{array}{l}50^{\circ} 16^{\prime} 05^{\prime \prime} \mathrm{N} \\
16^{\circ} 20^{\prime} 37^{\prime \prime}\end{array}$ & 645 & 120 & 11.3 & 596 & Schist & $\begin{array}{c}\text { modal } \\
\text { Cambisol }\end{array}$ & NW & 18 & 65 & $5 \mathrm{~A}$ & $\begin{array}{c}\text { AP, FS, FE, } \\
\text { BA, SA, } \\
\text { PA, UG, } \\
\text { PR }\end{array}$ \\
\hline
\end{tabular}

Notes: $\mathrm{GS}^{1}$ - growing season; ${ }^{2}$ Forest site type: $5 \mathrm{~F}$ - Abieto-Fagetum lapidosum mesotrophicum, $5 \mathrm{~A}$ - Acereto-Fagetum lapidosum, $6 \mathrm{~A}-$ Aceri-Piceeto-Fagetum lapidosum; ${ }^{3}$ Species: AP - Acer pseudoplatanus, FS - Fagus sylvatica, FE - Fraxinus excelsior, AG - Alnus glutinosa, AI - Alnus incana, SA - Sorbus aucuparia, PA - Picea abies, BA - Betula alba, AA - Abies alba, UG - Ulmus glabra, PR - Prunus avium. 


\section{Data collection}

The FieldMap technology (IFER-Monitoring and Mapping Solutions Ltd.) was used for the establishment of four PRP $50 \times 50 \mathrm{~m}$ in size $(0.25 \mathrm{ha})$ in 2015 . Using this system, the position and crown projections at a minimum of four directions perpendicular to each other were measured in the tree layer with diameter at breast height $(\mathrm{dbh})>4 \mathrm{~cm}$. In the tree layer dbh was measured with a metal calliper (accuracy $1 \mathrm{~mm}$ ) and total height and height to crown base with a Vertex laser hypsometer (accuracy $0.1 \mathrm{~m}$ ). In 30 dominant and co-dominant sycamore trees on each PRP the cores were sampled at dbh $(130 \mathrm{~cm})$ perpendicular to the trunk axis in a downslope and upslope direction.

For naturally regenerated saplings (height $\geq 50$ $\mathrm{cm}$, dbh $<4 \mathrm{~cm}$ ) the position, height and crown width were measured on all plot in the same year. One-year-old and older seedlings were measured in $10 \times 50 \mathrm{~m}$ transects. Height, height to crown base, position, crown width (accuracy $1 \mathrm{~cm}$ ) and browse damage in seedlings 1 year and older were measured. Seedlings less than 1 year in age were tallied for quantity and mortality. The number of sycamore seeds that fell onto the soil surface was evaluated in September to November in 2014-2016, number of seedlings and their mortality in the growing season in 2015 and 2016 was evaluated at the centre of the above-mentioned transect (on an area of $1 \times 50 \mathrm{~m}$ ).

\section{Data analysis}

Growth parameters, production, biodiversity, horizontal and vertical structure were evaluated for all individuals in the tree layer on the PRP. Tree volume was estimated by using volume equations published by Petráš \& Pajtík (1991). Height curves were constructed by using the Näslund height-diameter function (Näslund, 1936) with quality rating by coefficient of determination $\left(\mathrm{R}^{2}\right)$.

To evaluate various aspects of biodiversity, the following diversity indices were computed: Arten-profile index (Pretzsch, 2006), index of diameter differentiation (Füldner, 1995), species heterogeneity index (Shannon, 1948), species evenness index (Pielou, 1975), species richness index (Margalef, 1958) and total stand diversity index (Jaehne \& Dohrenbusch, 1997). Tab. 2 shows the criteria of structure indices.

To evaluate the spatial pattern of the stands Clark-Evans index (Clark \& Evans, 1954) and Ripley $L$-function (Ripley, 1981) were calculated. The PointPro 2 programme (Zahradnik \& Pus) was used to compute the characteristics that describe the horizontal distribution of individuals across a plot. The test of significance of deviations from the values expected for the random point pattern was performed by means of Monte Carlo simulations. The mean values were estimated as arithmetic means computed for 999 randomly generated point structures. Along with the measurements of horizontal structure on the PRP, stand density, crown projections area and crown closure were also calculated. Maps were made by using the ArcGIS programme (Esri).

Tree-ring increment series were individually cross-dated (removal of errors connected with the occurrence of missing tree rings) by using statistical tests in the PAST application (Hammer \& Harper) and they were visually inspected according to Yamaguchi (1991). If a tree ring was found to be missing, a tree ring of $0.01 \mathrm{~mm}$ in width was inserted in its place. Particular curves from PRP were detrended and an average tree ring series was created from them in the ARSTAN programme (Laboratory of Tree-Ring Research). The 60-year spline was applied (Grissino-Mayer et al., 1992). Negative pointer years were analyzed according to Schweingruber et al. (1990). For each tree the pointer year was tested as an extremely thin tree ring that does not reach $40 \%$ of the average of increments from the preceding 4 years. The occurrence of a negative year was proved if such a strong reduction in increment occurred in at least $20 \%$ of the trees on the plot. Average tree ring series from PRP in the Orlické hory Mts. were correlated with annual and monthly climate data (temperature, precipitation). The DendroClim software

Table 2. Overview of indices describing the stand diversity and their common interpretation

\begin{tabular}{|c|c|c|c|c|}
\hline Criterion & Quantifiers & Label & Reference & Evaluation \\
\hline Horizontal structure & $\begin{array}{l}\text { Aggregation } \\
\text { index }\end{array}$ & $R(\mathrm{C} \& \mathrm{Ei})$ & $\begin{array}{l}\text { Clark \& Evans } \\
\quad(1954)\end{array}$ & mean value $R=1$; aggregation $R<1$; \\
\hline Vertical diversity & $\begin{array}{l}\text { Arten-profile } \\
\text { index }\end{array}$ & $A$ (Pri) & Pretzsch (2006) & $\begin{array}{l}\text { range } 0-1 \text {; balanced vertical structure } A<0.3 \text {; selection forest } \\
\qquad A>0.9\end{array}$ \\
\hline $\begin{array}{l}\text { Structure differen- } \\
\text { tiation }\end{array}$ & $\begin{array}{l}\text { Diameter dif- } \\
\text { ferentiation }\end{array}$ & $T M_{d}(\mathrm{Fi})$ & Füldne & range $0-1$; low $T M_{d}<0.3$; very high differentiation $T M_{d}>0.7$ \\
\hline Species diversity & $\begin{array}{l}\text { Heterogeneity } \\
\text { Evenness } \\
\text { Richness }\end{array}$ & $\begin{array}{l}H^{\prime}(\text { Shi }) \\
E \text { (Pii) } \\
D \text { (Mai) }\end{array}$ & $\begin{array}{l}\text { Shannon (1948) } \\
\text { Pielou (1975) } \\
\text { Margalef (1958) }\end{array}$ & $\begin{array}{l}\text { minimum } H^{\prime}=0 \text {, higher } H^{\prime}=\text { higher values } \\
\text { range } 0-1 \text {; minimum } E=0 \text {, maximum } E=1 \\
\text { minimum } D=0 \text {, higher } D=\text { higher values }\end{array}$ \\
\hline Complex diversity & Stand diversity & B (J\&Di) & $\begin{array}{l}\text { Jaehne \& Dohren- } \\
\text { busch (1997) }\end{array}$ & $\begin{array}{c}\text { monotonous structure } B<4 \text {; uneven structure } B=6-8 \text {; very } \\
\text { diverse structure } B>9\end{array}$ \\
\hline
\end{tabular}


(DendroLab) was used to model diameter increment as dependent on climate-related variables. Temperature and precipitation data were collected at the meteorological station at Deštné v Orlických horách (656 m a.s.1.; GPS $\left.50^{\circ} 18^{\prime} 24^{\prime \prime} \mathrm{N}, 16^{\circ} 21^{\prime} 07^{\prime \prime} \mathrm{E}\right)$. In order to analyse the effect of overall meteorological conditions on growth, Sielianinov hydrothermal coefficient $(K)$ was used (Radzka \& Rymuza, 2015).

Statistical analyses were processed in the Statistica 12 software (StatSoft, Tulsa). Data were log-transformed to acquire normal distribution (tested by Shapiro-Wilk test). Differences in mean height of natural regeneration recruits and height of recruits not damaged and damaged by browsing were separately tested by one-way analysis of variance (ANOVA). To determine the combined effect of average annual temperature and annual sum of precipitation on diameter increment of sycamore, correlation quadratic model was used. Variances are shown by standard deviation $( \pm \mathrm{SD})$.

\section{Results}

\section{Growth parameters of tree layer}

The number of living trees ranged from 376 to 696 trees ha ${ }^{-1}$ (with sycamore at 244-496 trees ha-1) and a stand density index of $0.56-0.86$ (Tab. 3). The stand volume ranged between $378-545 \mathrm{~m}^{3} \mathrm{ha}^{-1}$, while sycamore accounted for 175-392 $\mathrm{m}^{3} \mathrm{ha}^{-1}$, and admixed tree species (Fagus sylvatica, Fraxinus excelsior, Alnus glutinosa, Alnus incana, Sorbus aucuparia, Picea abies, Betula pendula, Abies alba, Ulmus glabra, Prunus avium) accounting for the rest. The highest total stand volume $\left(545 \mathrm{~m}^{3} \mathrm{ha}^{-1}\right)$ was found on PRP 1 , and the lowest $\left(378 \mathrm{~m}^{3} \mathrm{ha}^{-1}\right)$ on PRP 2. The highest stand volume for sycamore $\left(82.0 \% ; 392 \mathrm{~m}^{3} \mathrm{ha}^{-1}\right)$ was on PRP 4 and the lowest $\left(32.1 \% ; 175 \mathrm{~m}^{3} \mathrm{ha}^{-1}\right)$ on PRP 1 . Periodic annual increment of stand currently fluctuated in the range of 8.7-9.8 $\mathrm{m}^{3} \mathrm{ha}^{-1} \mathrm{y}^{-1}$ (in sycamore $4.0-7.4 \mathrm{~m}^{3}$ $\mathrm{ha}^{-1} \mathrm{y}^{-1}$ ) and mean annual increment was $6.1-7.4 \mathrm{~m}^{3}$ $\mathrm{ha}^{-1} \mathrm{y}^{-1}$ (in sycamore $2.8-5.0 \mathrm{~m}^{3} \mathrm{ha}^{-1} \mathrm{y}^{-1}$ ). The total stand basal area ranged between 33.0 and $48.3 \mathrm{~m}^{2}$ $\mathrm{ha}^{-1}$ and 15.6-32.4 $\mathrm{m}^{2} \mathrm{ha}^{-1}$ for sycamore. Crown closure was in the range of 91.2-96.8\% and crown projection areas ranged from 2.43 to $3.43 \mathrm{ha}$.

\section{Diameter and height structure of tree layer}

The stands were mostly composed of two or three storeys with varied differentiation of the vertical canopy. Average dbh on all PRP ranged from 29.3 to 35.2 $\mathrm{cm}$ for all trees and from 26.7 to $33.1 \mathrm{~cm}$ for sycamore (Fig. 2). On PRP the largest range of diameter classes was found for the range of $28-44 \mathrm{~cm}$ (the representation of the diameter class of small wood 4-8 $\mathrm{cm}$ was the highest on PRP 4), in sycamore it was $24-44 \mathrm{~cm}$. Fig. 3 illustrates the relationship between $\mathrm{dbh}$ and tree height on the PRP $\left(\mathrm{R}^{2}=0.85-0.88\right)$.

The tallest sycamore trees on the PRP reached 28-32 m. The maximum height for admixed Norway spruce (Picea abies [L.] Karst.) was 32-41 $\mathrm{m}$ and for European beech $30-33 \mathrm{~m}$. The height of the crown base of sycamore varied considerably. In the tree understorey it was mostly in the range of $2-8 \mathrm{~m}$ and in the overstorey 9-17 $\mathrm{m}$. The slenderness ratio decreases with dbh in all studied tree species while a more pronounced decrease, with the least variability, was observed in the thinnest trees of sycamore when the variance of values was minimum.

\section{Radial growth}

In the sycamore study sites of the Orlické hory Mts. region, the average tree-ring width in the 50year period was lowest on PRP $42.6 \mathrm{~mm}( \pm 0.4 \mathrm{SD})$, on PRP $33.2 \mathrm{~mm}( \pm 0.4 \mathrm{SD})$, on PRP $23.2 \mathrm{~mm}( \pm$

Table 3. Basic stand characteristics of the permanent research plots 1-4

\begin{tabular}{|c|c|c|c|c|c|c|c|c|c|c|c|c|c|c|}
\hline & $\mathrm{t}$ & $\mathrm{dbh}$ & $\mathrm{h}$ & $\mathrm{f}$ & $\mathrm{v}$ & $\mathrm{N}$ & G & V & HDR & PAI & MAI & $\mathrm{CC}$ & $\mathrm{CPA}$ & SDI \\
\hline PRP & (y) & $(\mathrm{cm})$ & (m) & & $\left(\mathrm{m}^{3}\right)$ & $\left(\right.$ trees ha $\left.^{-1}\right)$ & $\left(\mathrm{m}^{2} \mathrm{ha}^{-1}\right)$ & $\left(\mathrm{m}^{3} \mathrm{ha}^{-1}\right)$ & & $\left(m^{3} h^{-1} y^{-1}\right)$ & $\left(m^{3} h^{-1} y^{-1}\right)$ & $(\%)$ & (ha) & \\
\hline \multicolumn{15}{|c|}{ Sycamore maple } \\
\hline 1 & 63 & 26.7 & 20.36 & 0.547 & 0.624 & 280 & 15.6 & 175 & 76.3 & 4.0 & 2.78 & 76.8 & 1.46 & 0.30 \\
\hline 2 & 64 & 33.1 & 23.03 & 0.525 & 1.041 & 244 & 21.0 & 254 & 69.6 & 6.3 & 3.97 & 84.0 & 1.83 & 0.36 \\
\hline 3 & 75 & 28.7 & 23.32 & 0.501 & 0.756 & 496 & 32.1 & 375 & 81.3 & 6.5 & 5.00 & 88.4 & 2.15 & 0.59 \\
\hline 4 & 79 & 31.5 & 20.42 & 0.593 & 0.943 & 416 & 32.4 & 392 & 64.8 & 7.4 & 4.96 & 91.3 & 2.44 & 0.57 \\
\hline \multicolumn{15}{|c|}{ All tree layer } \\
\hline 1 & 83 & 35.2 & 22.78 & 0.549 & 1.216 & 448 & 43.5 & 545 & 64.7 & 9.0 & 6.57 & 91.2 & 2.43 & 0.67 \\
\hline 2 & 61 & 33.5 & 22.06 & 0.518 & 1.007 & 376 & 33.0 & 378 & 65.9 & 9.1 & 6.20 & 94.3 & 2.87 & 0.56 \\
\hline 3 & 77 & 29.7 & 22.47 & 0.527 & 0.820 & 696 & 48.3 & 571 & 75.7 & 9.8 & 7.40 & 96.8 & 3.43 & 0.86 \\
\hline 4 & 79 & 29.3 & 17.86 & 0.662 & 0.797 & 600 & 40.3 & 478 & 61.0 & 8.7 & 6.05 & 96.4 & 3.33 & 0.72 \\
\hline
\end{tabular}

Notes: $\mathrm{t}$ - average stand age, $\mathrm{dbh}$ - mean quadratic breast height diameter, $\mathrm{h}$ - mean height, $\mathrm{f}-\mathrm{form}$ factor, $\mathrm{v}-\mathrm{mean}$ tree volume, $\mathrm{N}$ number of trees, G - basal area, V - stand volume, HDR - slenderness ratio, PAI - periodic annual increment, MAI - mean annual increment, CC - canopy closure, CPA - crown projection area, SDI - stand density index. 
PRP 1

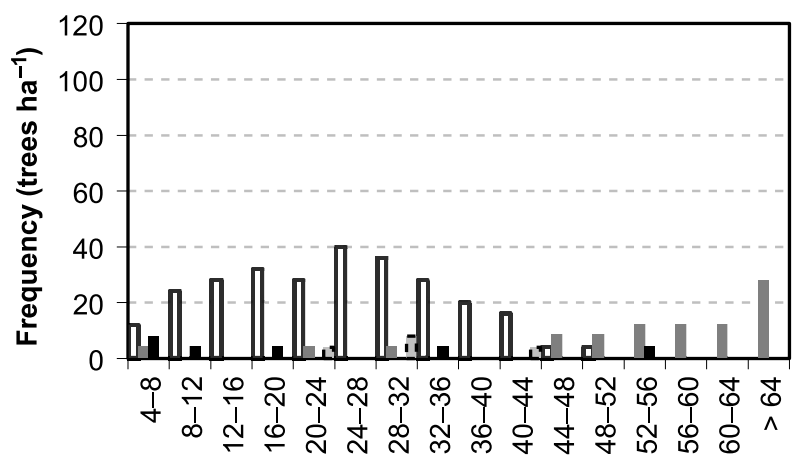

Diameter class $(\mathrm{cm})$

\begin{tabular}{|ll|}
\hline 口Acer pseudoplatanus & Picea abies \\
Gagus sylvatica & - Sorbus aucuparia \\
\hline
\end{tabular}

PRP 3

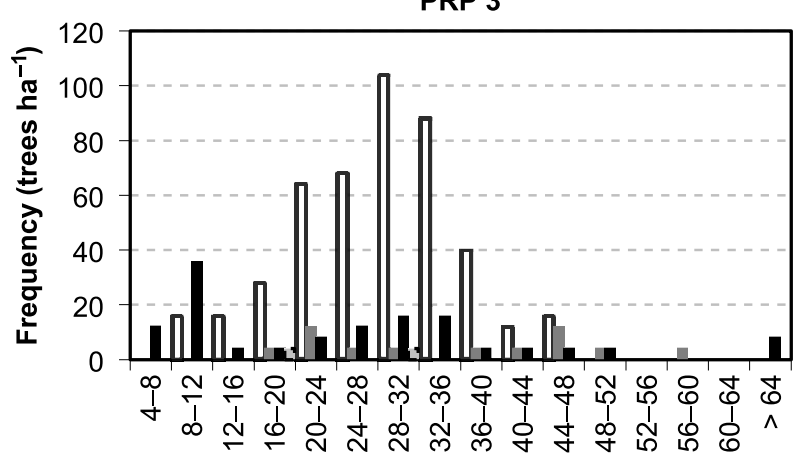

Diameter class $(\mathrm{cm})$

\begin{tabular}{|ll|}
\hline 口Acer pseudoplatanus & Picea abies \\
-Fagus sylvatica & : Sorbus aucuparia \\
\hline
\end{tabular}

PRP 2

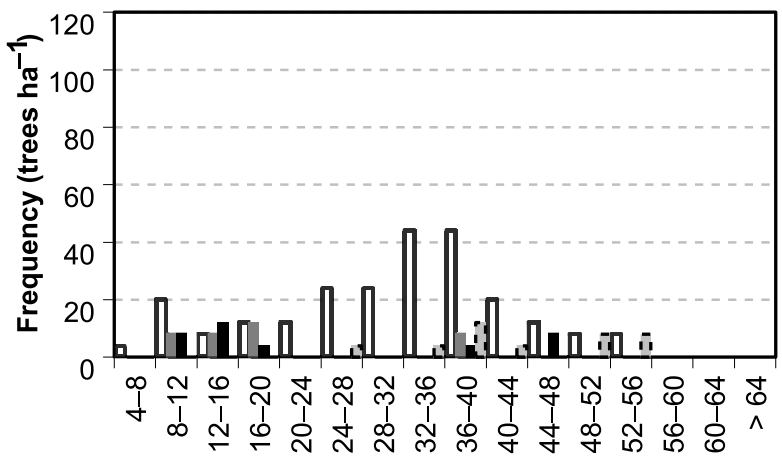

Diameter class $(\mathbf{c m})$

\begin{tabular}{ll} 
口Acer pseudoplatanus & Picea abies \\
- Fagus sylvatica & - Alnus glutinosa \\
\hline
\end{tabular}

PRP 4

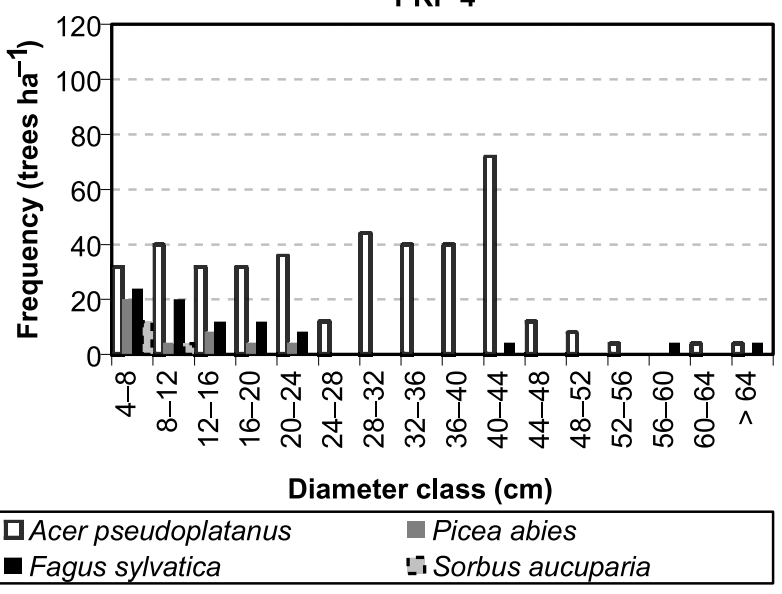

Fig. 2. Histogram of diameter classes indicatedby tree species on the permanent research plots

$0.8 \mathrm{SD}$ ) and the highest increment on PRP $13.3 \mathrm{~mm}$ ( \pm 0.6 SD).

We observed three distinct patterns of tree growth. From 1960 to 1963, an increase of radial increment was observed, subsequently a relatively

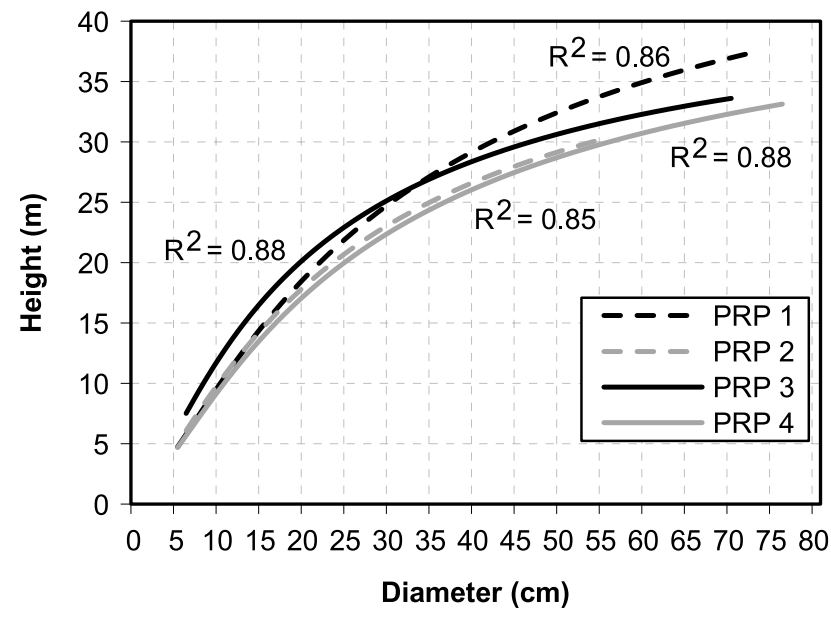

Fig. 3. The relationship between diameter and tree height with coefficient of determination $\left(\mathrm{R}^{2}\right)$ on the permanent research plots $1-4$ balanced growth followed during the years 1963 to 1975 and declining growth was found from 1976 to 2014 (Fig. 4). The low radial increment that occurred during 1952, 1996 and 2007 confirmed them as negative pointer years. The period from January through April 1996 (in January only $9 \mathrm{~mm}$; long-term mean $96 \mathrm{~mm}$ ), the driest period from January to April in 1961-2014, and extremely frosty winter $\left(-4.2^{\circ} \mathrm{C}\right.$, long-term mean $-2.3^{\circ} \mathrm{C}$ ) caused decrease in radial increment by $42 \%$. In 2007, the summer temperatures were extremely hot (the hottest June $16.3^{\circ} \mathrm{C}$ in 1961-2014, long-term mean $13.4^{\circ} \mathrm{C}$ ), a typical characteristic of these negative pointer years.

A comparison of average tree-ring curves of sycamore indicated their high mutual correspondence when the t-test $\geq 3.4$ showed the reliability of synchronization. Therefore, it was possible to construct the regional standardized ring-width chronology for sycamore in the Orlické hory Mts. (Fig. 5).

Comparisons of diameter increment with climatic factors found significant relationships. In the Orlické hory Mts. region diameter increment in 1961-2014 was significantly positively correlated $(\alpha=0.05)$ with temperature in September of the previous year 


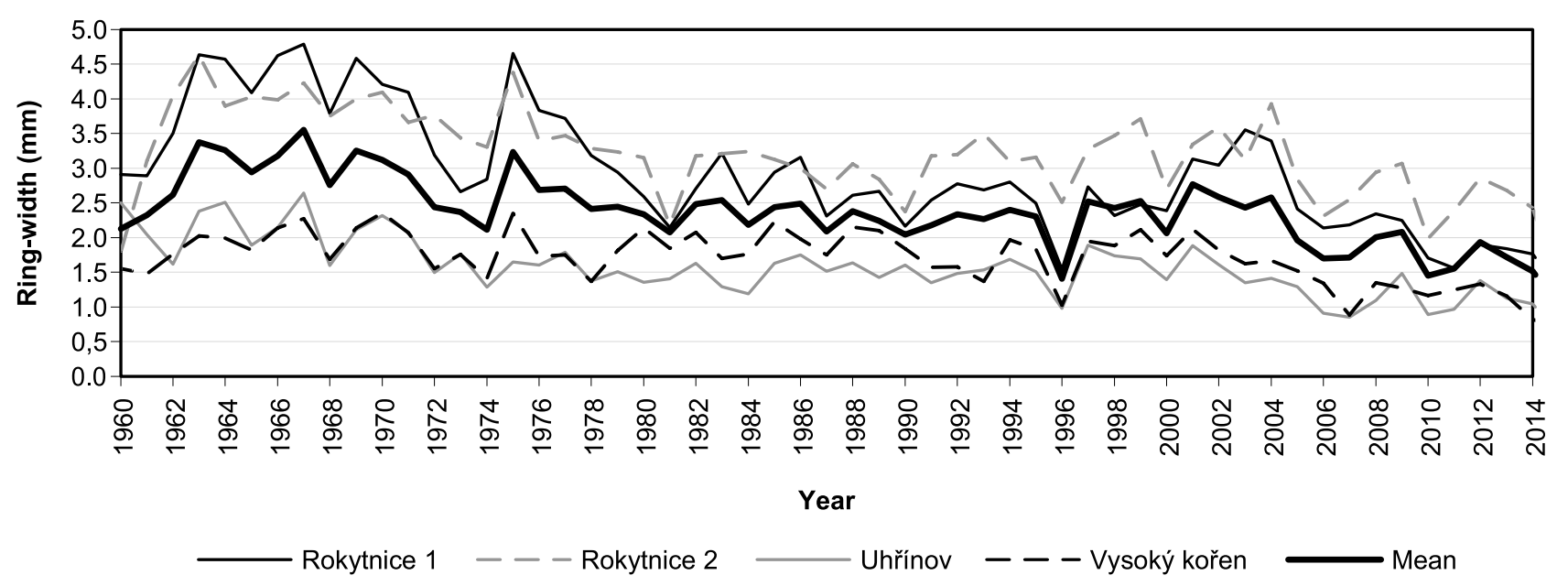

Fig. 4. Annual ring-width chronologies for the permanent research plots 1-4 and the entire study area of Orlické hory Mts.

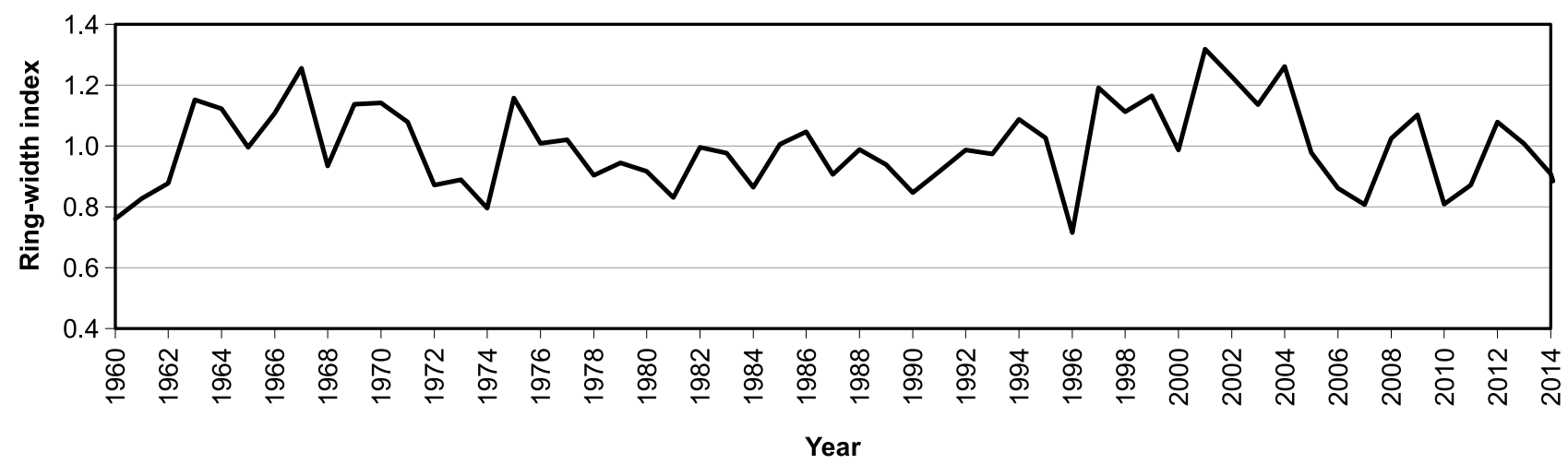

Fig. 5. Average annual ring increment in the entire study area of the Orlické hory Mts. after removing the age trend

$(r=-0.23)$ and in April of current year $(r=-0.24)$. Annual increment was significantly negatively correlated with mean temperature in months during the dormant season (December, January and March $r=-0.23-0.33$; Fig. 6). Significant positive correlations were also found between the amount of precipitation in July and October of the previous year ( $\mathrm{r}$ $=0.27$ to 0.32 ) and March of the current year ( $r=$ 0.23; Fig. 6). Moreover, soil moisture had effect on radial growth of sycamore on PRP. Mean temperature had the highest effect on radial growth on the waterlogged PRP 2 (4 significant months), while there was almost no effect of precipitation (only positive effect in October of the previous year). Conversely on PRP 3 with the lowest soil moisture, there was observed the highest positive effect of precipitation on increment (4 significant months; moreover, June of the previous year).

The main positive factor influencing the diameter increment of sycamore in study area was identified

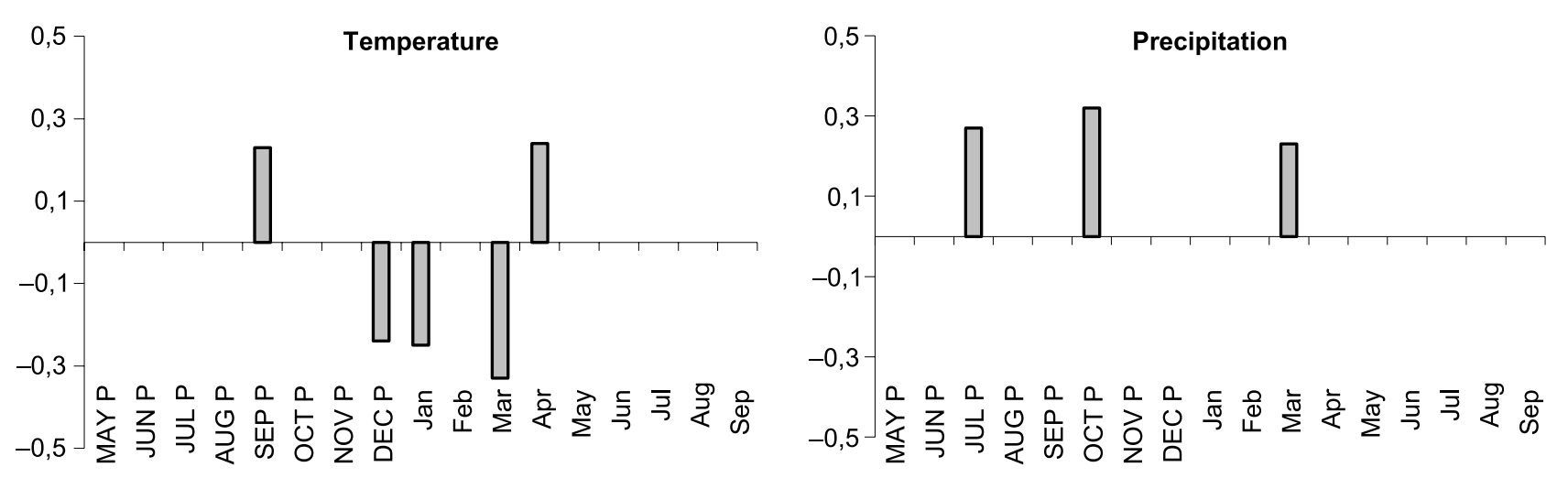

Fig. 6. The values of correlation coefficients of the regional residual index tree-ring chronology with the monthly temperature (left) and precipitation (right) from May of the previous year (P) to September of the current year for the period 1961-2014; correlation coefficients with significant values $(\alpha=0.05)$ are shown 


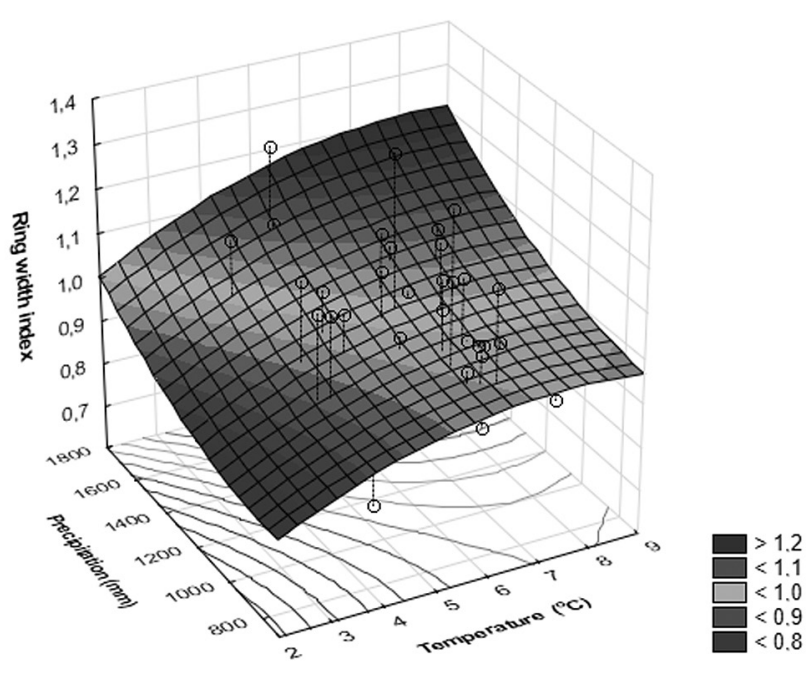

Fig. 7. Response of ring width index of sycamore maple to annual sum of precipitation and annual mean temperature (correlation quadratic model, years 1961-2014)

the precipitation (Fig. 7). Annual sum of precipitation had higher effect $(\mathrm{r}=0.21, \mathrm{p}=0.15)$ on radial growth compared to annual average temperature $(r=0.09, p=0.49)$. Diameter increment increased with increasing precipitation, while optimal growth was observed in annual temperature range from 7.5 to $8.5^{\circ} \mathrm{C}$. According to hydrothermal index $K$, climate (combination of temperature and precipitation) had the significant positive impact on radial growth in July $(r=0.37, p<0.01)$ and October of the previous year $(r=0.33, p<0.05)$.

\section{Tree layer biodiversity}

Vertical structure according to $A$ index was moderately to strongly-varied $(A=0.45-0.63$; Tab. 4). Diameter differentiation was medium $\left(T M_{d}=0.36\right.$ 0.50). Species biodiversity $H^{\prime}$ was found to be at a medium level $\left(H^{\prime}=0.33-0.46\right)$. Species evenness ranged from medium to high $(E=0.36-0.65)$ diversity. Total stand diversity $B$ suggested an uneven structure on PRP 2 and $3(B=7.74-0.78)$ and a more diverse structure on PRP 1 and $4(B=8.48-8.80)$.

Horizontal structure of all tree species was mostly random (Tab. 4, Fig. 8). The exception was PRP 3,

Table 4. Indices of the tree layer biodiversity on the permanent research plots $1-4$

\begin{tabular}{cccccccc}
\hline PRP & $\begin{array}{c}\mathrm{A} \\
(\mathrm{Pri})\end{array}$ & $\begin{array}{c}\mathrm{TM}_{\mathrm{d}} \\
(\mathrm{Fi})\end{array}$ & $\begin{array}{c}\mathrm{H}^{\prime} \\
(\mathrm{Si})\end{array}$ & $\begin{array}{c}\mathrm{E} \\
(\mathrm{Pii})\end{array}$ & $\begin{array}{c}\mathrm{D} \\
(\mathrm{Mai})\end{array}$ & $\begin{array}{c}\mathrm{R} \\
(\mathrm{C} \& \mathrm{Ei})\end{array}$ & $\begin{array}{c}\mathrm{B} \\
\text { (J\&Di) }\end{array}$ \\
\hline 1 & 0.454 & 0.494 & 0.463 & 0.595 & 0.819 & 1.081 & 8.795 \\
2 & 0.631 & 0.391 & 0.452 & 0.647 & 0.675 & 1.073 & 7.737 \\
3 & 0.601 & 0.358 & 0.403 & 0.577 & 0.611 & 0.883 & 7.822 \\
4 & 0.465 & 0.427 & 0.329 & 0.364 & 1.094 & 1.028 & 8.480 \\
\hline
\end{tabular}

Notes: $A$ - Arten-profile index, $T M_{d}$ - diameter differentiation index, $H^{\prime}$ - species heterogeneity index (entropy), $E$ - species evenness index, $D$ - species richness index, $R$ - aggregation index, $B$ - total diversity index. where according to the $R$ index, the distribution of tree layer individuals was significantly aggregated $(\alpha$ $=0.05)$. The sycamores of the tree layer were randomly distributed on PRP 1 and 4. On PRP 2 and 3 the spatial pattern of trees was significantly aggregated according $R$ index. The mostly random distribution of tree layer individuals according to their distance followed from Ripley's $L$-function, only on PRP 3 the spatial pattern was aggregated at distance shorter than $3 \mathrm{~m}$. On the other hand, the random spatial pattern of sycamore in the tree layer occurred on PRP 4, on PRP 1 only at distance shorter than 5 $\mathrm{m}$ and on PRP 2 shorter than $6.5 \mathrm{~m}$. In the other cases it was an aggregated distribution, being the most pronounced on PRP 3 (Fig. 9).

\section{Natural regeneration}

The number of maple seeds that fell on the PRP was highly variable during 2015 , considered a seed-medium to rich year. Seed fall within the transect on PRP 1 was $16-144$ seeds (36 seeds on average), on PRP 2 it was $4-76$ seeds $\mathrm{m}^{-2}$ (30 seeds), on PRP $30-54$ seeds $\mathrm{m}^{-2}$ (18 seeds) and on PRP 4 $18-126$ seeds $\mathrm{m}^{-2}$ (52 seeds). Across all four PRP, the average was 34 seeds $\mathrm{m}^{-2}$. The weaker seed year 2016 was also variable. Number of seeds was on transect on PRP 1 in the interval 6-68 seeds $\mathrm{m}^{-2}$ ( 24 seeds), on PRP 2 it was $2-52$ seeds (16 seeds), on the PRP $30-36$ seeds (14 seeds) and on PRP 4 it was 4-90 seeds ( 26 seeds). The whole average of all four PRP was 20 seeds $\mathrm{m}^{-2}$.

In 2016 there was found on average 17 seedlings $\mathrm{m}^{-2}$ (PRP 1 on average 20 seedlings, PRP 215 seedlings, PRP 39 seedlings and PRP 424 seedlings). The year 2014 was seed-poor productive compared to year 2015, averaging only 9 seedlings $\mathrm{m}^{-2}$ across all PRP. The minimum number was observed on PRP $30-12$ seedlings $\mathrm{m}^{-2}$ (on average 3 seedlings), while maximum density was reached on PRP 4 2-46 seedlings $\mathrm{m}^{-2}$ (14 seedlings). As of $30^{\text {th }}$ November 2015, the mortality of seedlings was very high due to herbivory by brown hare (Lepus europaeus Pallas) and also by drought, when mortality ranged from 84 to $93 \%$ (on average $89 \%$ ), which corresponds to $0.2-1.4$ seedlings $\mathrm{m}^{-2}$. The total number of natural regeneration ranged in 2015 from 1,532 (PRP 3) to 4,244 (PRP 4) recruits ha-1 (Tab. 5). On average, European beech accounts for $47 \%$ of the total, sycamore $23 \%$, European rowan (Sorbus aucuparia L.) 9\%, and black alder (Alnus glutinosa [L.] Gaertn) 8\%. The percentages of the remaining tree species were below $4 \%$.

Species richness of natural regeneration was very high on PRP 1 and 4, and high on PRP 2 and 3 (Tab. 5 ). Species heterogeneity of natural regeneration was very high. Species evenness (index $E$ ) was very high on PRP 1-3 and high on PRP 4 (Tab. 5). The spatial 
pattern of recruits on all plots was significantly aggregated $(R=0.52-0.77)$ with the highest tendency to aggregation on PRP 1 (Fig. 8).

Height and diameter differentiation of the natural regeneration of the PRP was limited by browsing

PRP 1

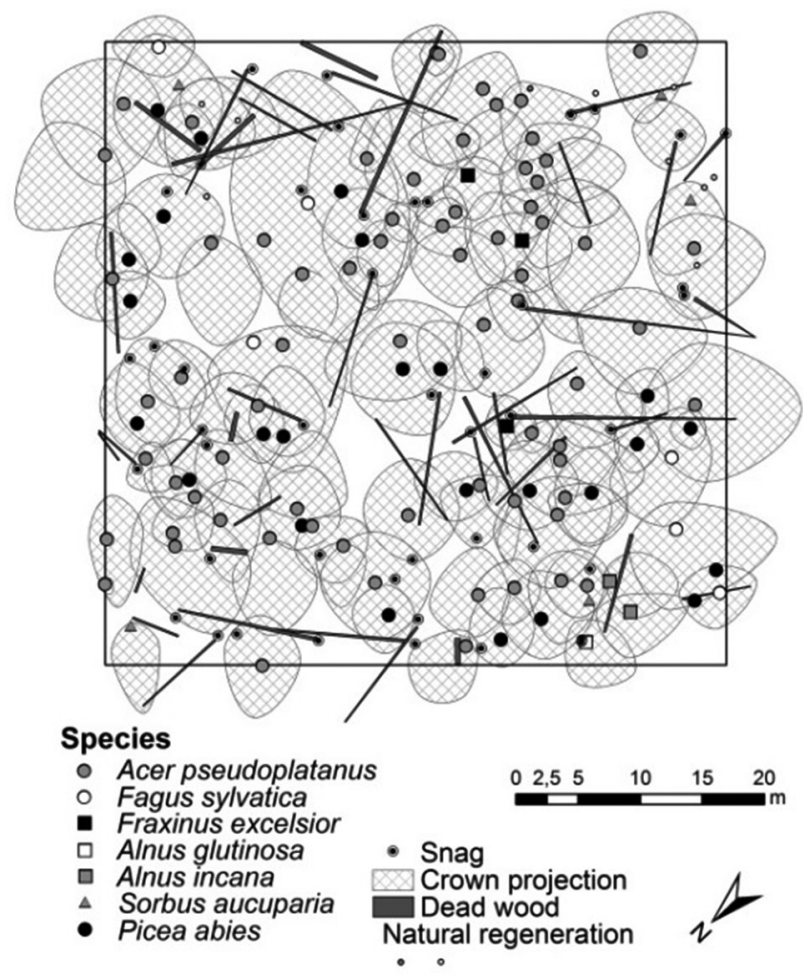

PRP 3

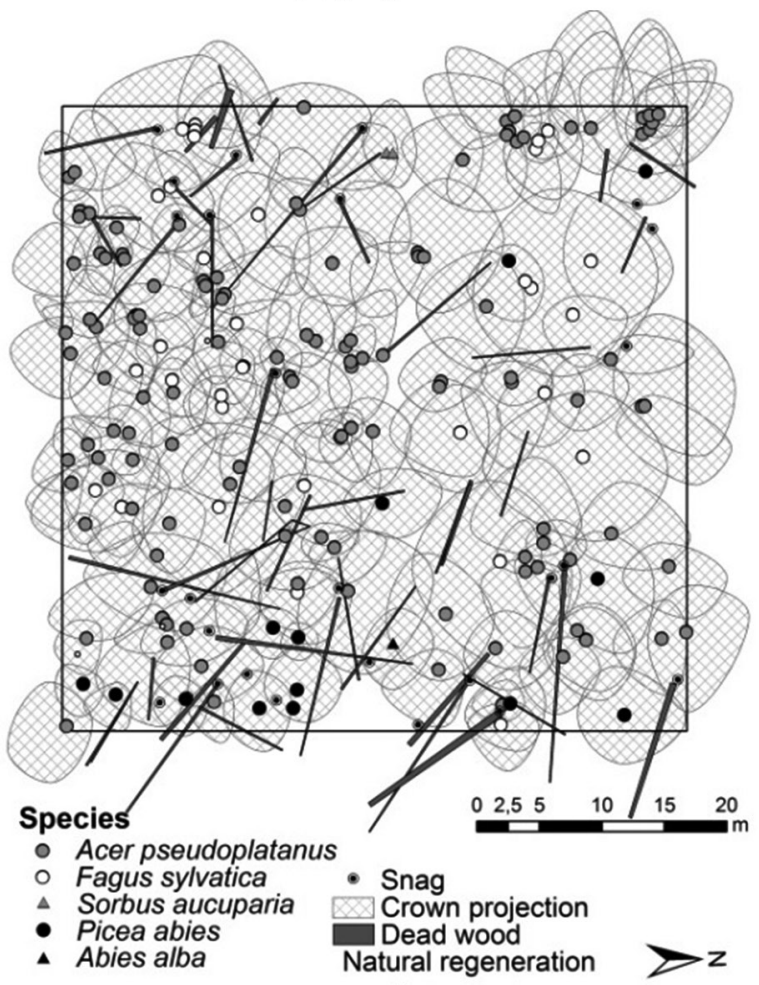

pressure mainly from roe deer. The height structure of natural regeneration was left-skewed while the highest number of recruits belongs to height classes below $100 \mathrm{~cm}$ (78.2-97.9\%; Fig. 10). The percentage of recruits higher than $50 \mathrm{~cm}$ was low $(15.2-17.6 \%$

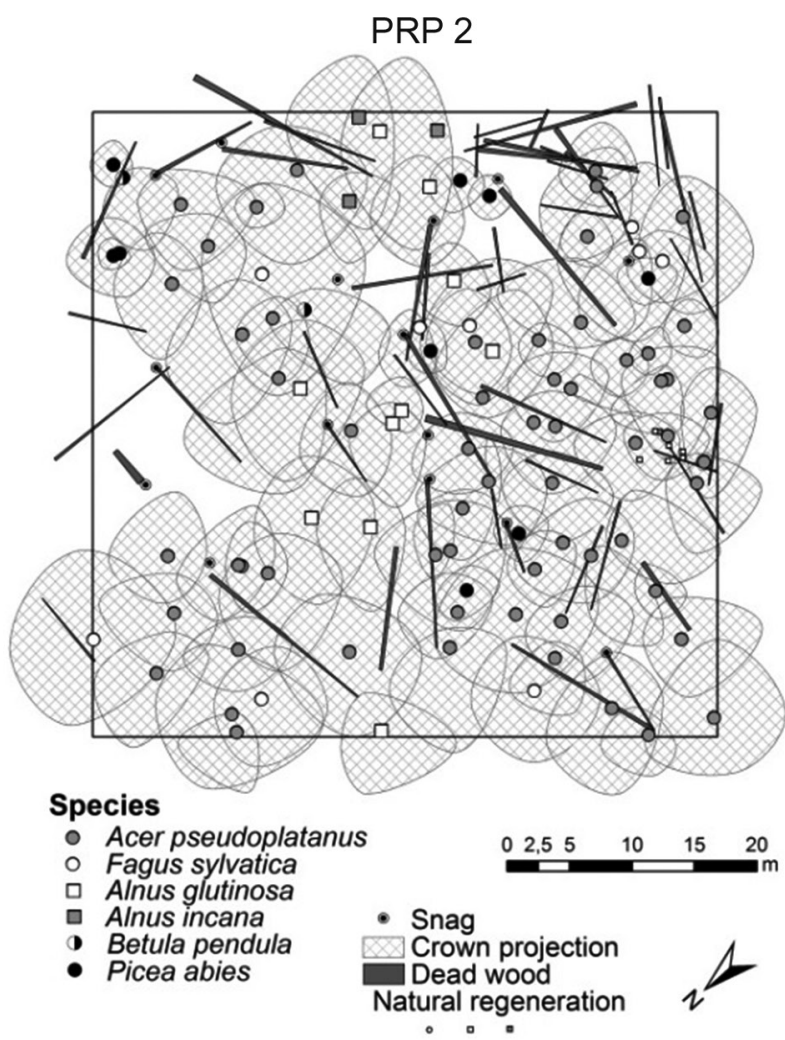

PRP 4

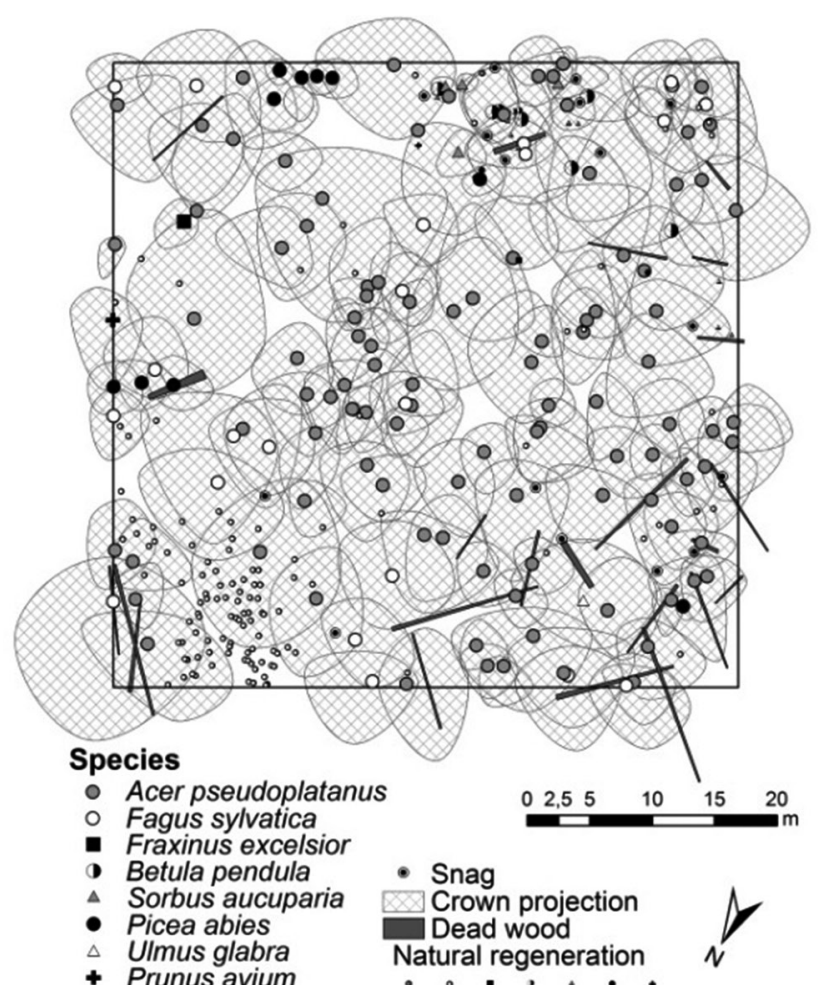

Fig. 8. Horizontal structure of the tree layer and natural regeneration on the permanent research plots 1-4 
Table 5. Indices of the species diversity and per-hectare numbers (share) of natural regeneration specified according to main tree species on the permanent research plots

\begin{tabular}{|c|c|c|c|c|c|c|c|c|c|}
\hline \multirow{2}{*}{ PRP } & \multirow{2}{*}{$\begin{array}{c}\mathrm{D} \\
\text { (Mai) }\end{array}$} & \multirow{2}{*}{$\begin{array}{l}\mathrm{H}^{\prime} \\
(\mathrm{Shi})\end{array}$} & \multirow{2}{*}{$\begin{array}{c}\mathrm{E} \\
(\mathrm{Pii})\end{array}$} & Acer pseudoplatanus & Fagus sylvatica & Alnus glutinosa & Sorbus aucuparia & Other tree species & Total density \\
\hline & & & & $\%$ & $\%$ & $\%$ & $\%$ & $\%$ & recruits ha- ${ }^{-1}$ \\
\hline 1 & 0.778 & 1.482 & 0.761 & 27.4 & 42.9 & 13.1 & 10.3 & 6.3 & 2240 \\
\hline 2 & 0.665 & 1.565 & 0.873 & 26.0 & 38.5 & 21.7 & 2.3 & 11.5 & 1852 \\
\hline 3 & 0.545 & 1.170 & 0.727 & 31.6 & 55.7 & 0.4 & 9.6 & 2.7 & 1532 \\
\hline 4 & 0.958 & 1.310 & 0.596 & 12.4 & 60.5 & 0.5 & 15.8 & 10.8 & 4244 \\
\hline
\end{tabular}

Notes: $D$ - species richness index, $H^{\prime}$ - species heterogeneity index (entropy), $E$ - species evenness index.

on PRP $1-3$ and $39.8 \%$ on PRP 4 ). No more than $0.5 \%$ of the sycamore seedlings with primary leaves survived in 2015 due to browsing by brown hares. Natural regeneration had the largest height differentiation and age-range structure on PRP 4 (Fig. 10). The average height of recruits was distinctly taller $\left(\mathrm{F}_{(3,489)}=21.3, \mathrm{P}<0.001\right)$ on PRP $4(67.0 \mathrm{~cm} \pm 4.3$ SD) than on PRP $3(28.8 \pm 3.0$ SD) and PRP 1 (27.9 $\pm 2.5 \mathrm{SD})$; the smallest height was on PRP 2 (27.7 $\pm 2.1 \mathrm{SD})$.

\section{PRP 1}

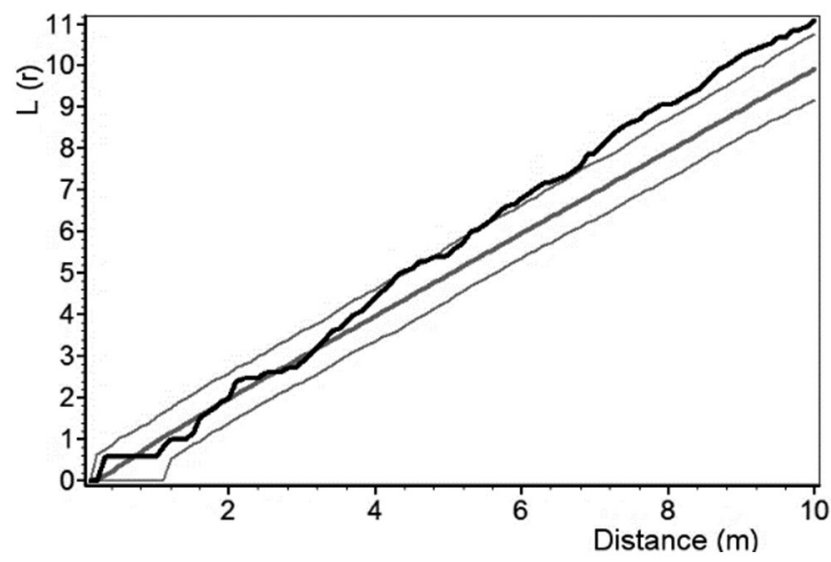

PRP 3

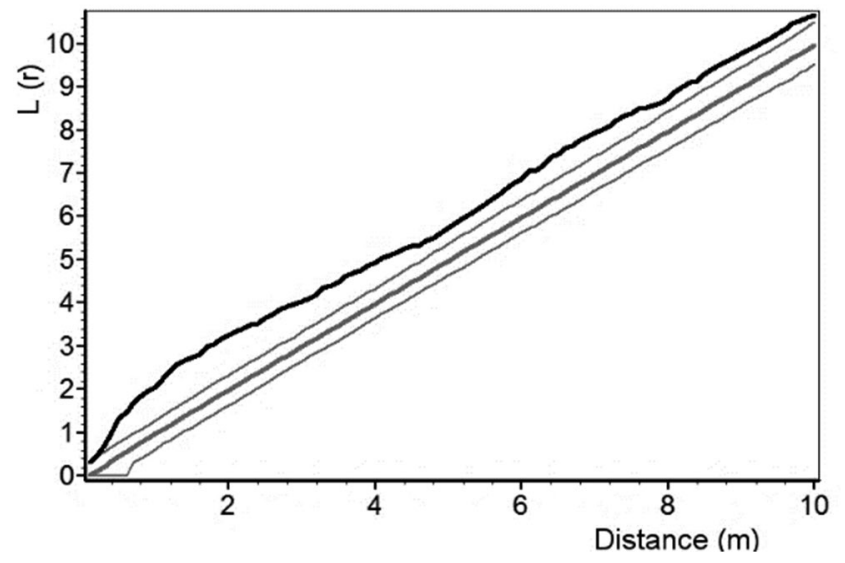

A comparison of average heights of natural regeneration without damage and individuals reduced by browsing showed that ungulates had a significant influence on the growth of natural regeneration $\left(\mathrm{F}_{(1,}\right.$ $\left.{ }_{491)}=134.7, \mathrm{P}<0.001\right)$. The highest losses due to browsing of terminal shoots occurred in sycamore (96\%), European rowan (92\%), silver fir (Abies alba Mill.; 90\%), wild cherry (85\%), Scots elm (Ulmus glabra Huds.; $82 \%$ ), while the relatively lowest losses are incurred in Norway spruce and alders (Alnus sp.

\section{PRP 2}

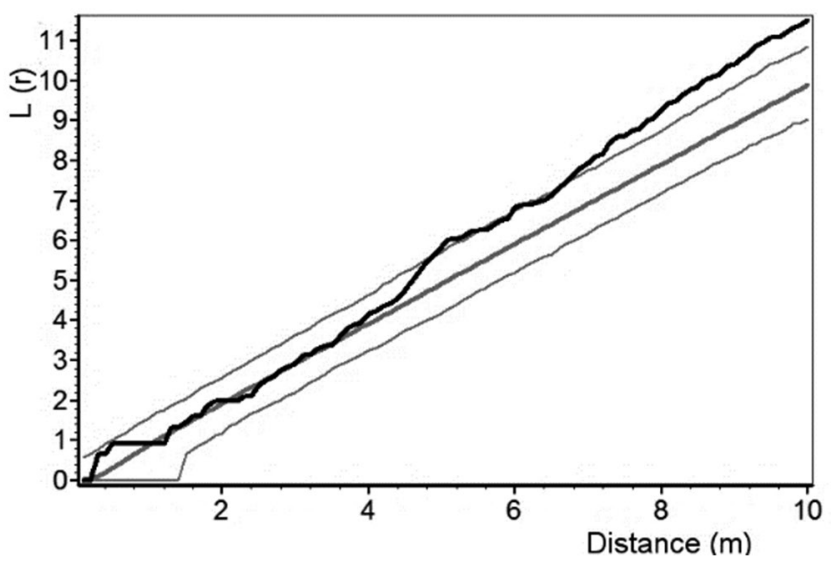

PRP 4

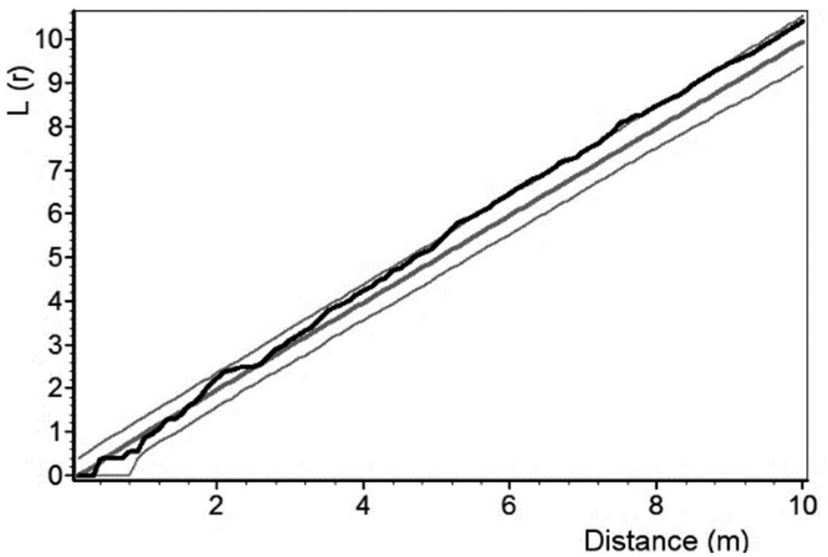

Fig. 9. Horizontal structure of sycamore maple on the permanent research plots expressed by the $L$-function; the black line represents the $L$-function for real distances of trees; the bold gray line represents the mean course for random spatial distribution of trees and the two thinner central curves represent $95 \%$ interval of reliability; when the black line of tree distribution on the PRP is below (above) this interval, it indicates a tendency of trees toward regular distribution (aggregation) 

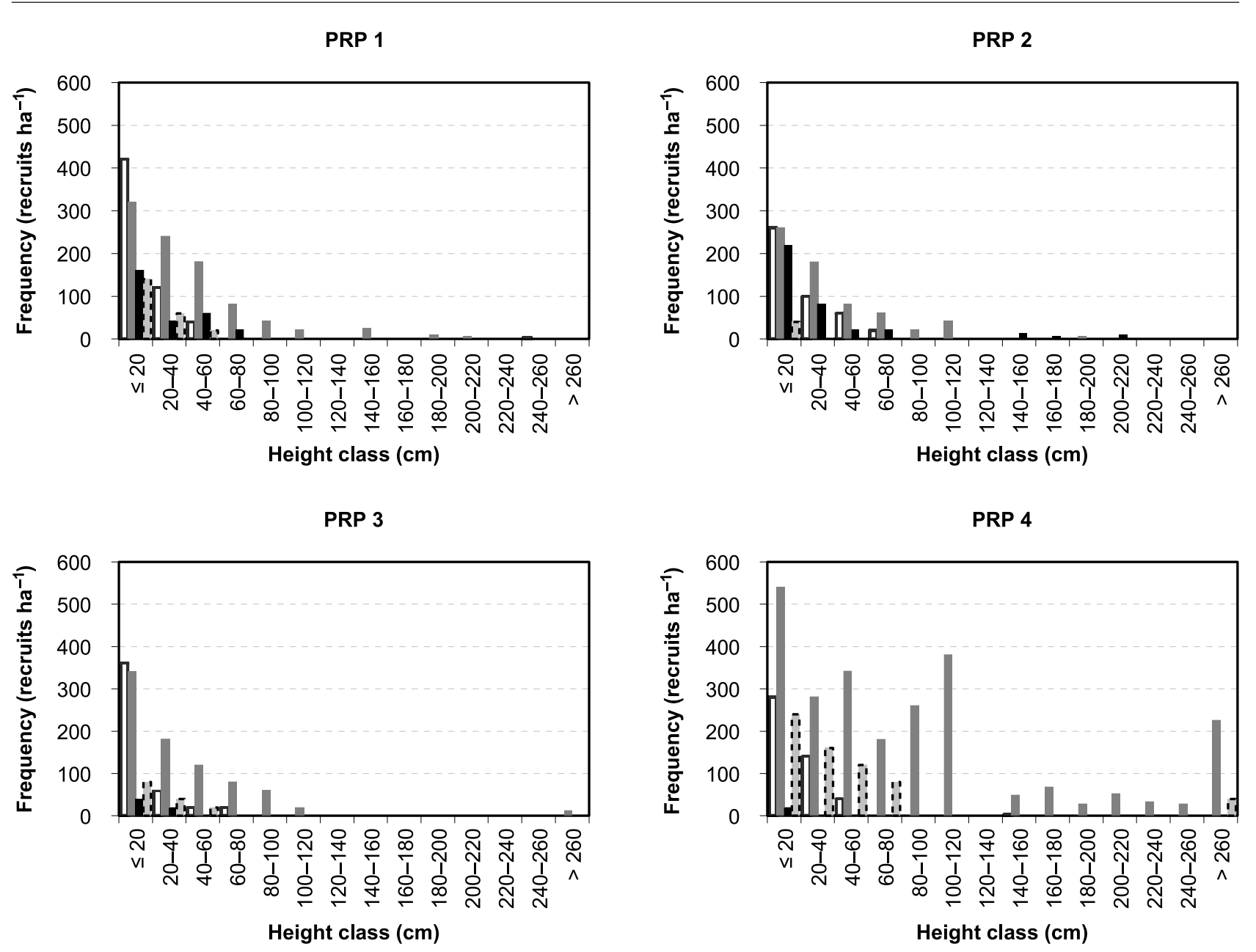

口Sycamore $\quad$ Fir Beech LiRowan

Fig. 10. Histogram of the height classes of natural regeneration of main tree species on the permanent research plots 1-4

$<50 \%$ ). Natural regeneration of European beech was substantially eliminated due to the beechnut caching by wildlife (in the range of $64-91 \%$ on PRP in 2015). In terms of phytocoenology, the lowest damages were observed on PRP 2 with the largest herbal and moss cover.

\section{Discussion}

In our study the stand volume of mixed-species forests with dominant sycamore varied from 378 to $571 \mathrm{~m}^{3} \mathrm{ha}^{-1}$ while the sycamore share amounted to 175-392 $\mathrm{m}^{3} \mathrm{ha}^{-1}$. In southern Sweden, comparable results were obtained in stands with dominant sycamore maple at 60 years of age where the sycamore volume was 198 to $361 \mathrm{~m}^{3} \mathrm{ha}^{-1}$ (Sjöstedt, 2012). However, in that study, the basal area of sycamore individuals was slightly larger and its range was also larger (22-45 $\left.\mathrm{m}^{2} \mathrm{ha}^{-1}\right)$ than on our PRP (16-32 $\mathrm{m}^{2}$ $\left.\mathrm{ha}^{-1}\right)$. The average height of sycamore was $2-5 \mathrm{~m}$ less in the case of Swedish sites. On PRP in the Orlické hory Mts. the average height of sycamore individuals was from 20.4 to $23.3 \mathrm{~m}$. These values correspond to site class 3 and 2 according to Danish yield tables (Kjølby, 1958).

The number of sycamore trees on plots in southern Sweden was significantly higher (340-800 trees ha-1; Sjöstedt, 2012) than on our PRP in the Orlické hory Mts. (244-496 trees ha-1), while stand volume was comparable on both localities. However, in most studies the stand volume with sycamore was derived from growth tables (cf. Hein et al., 2009), which resulted in its wide range according to site and stand conditions [e.g. in Sweden 32-407 $\mathrm{m}^{3} \mathrm{ha}^{-1}$ according to Sjöstedt (2012) and in Denmark 274-766 $\mathrm{m}^{3} \mathrm{ha}^{-1}$ according to Kjølby (1958)]. Schrober (1995) reported that the stand volume production of sycamore in the best yield class in Germany was around $1050 \mathrm{~m}^{3} \mathrm{ha}^{-1}$ and was much higher than in beech, $\left(546 \mathrm{~m}^{3} \mathrm{ha}^{-1}\right.$ at 80 years of age) or ash $\left(555 \mathrm{~m}^{3} \mathrm{ha}^{-1}\right)$. Lockow (2004) from Germany stated that sycamore of $30 \mathrm{~m}$ in height exceeded the ash volume by $180 \mathrm{~m}^{3} \mathrm{ha}^{-1}$ while beech had a larger volume than sycamore only at a height above $30 \mathrm{~m}$. If the stand volumes of sycamore and beech stands from similar site conditions of the Orlické hory Mts. were 
compared, the obtained values were similar (175-392 $\mathrm{m}^{3} \mathrm{ha}^{-1}$ in sycamore and $194-484 \mathrm{~m}^{3} \mathrm{ha}^{-1}$ in beech; Králíček et al., 2017). Dynamics of diameter increment is in close correlation with volume increment. In sycamore, similarly like in the other tree species, diameter increment and natural formation of crowns apparently depend on site and stand conditions that are influenced by silvicultural practices (Hemery et al., 2005; Hein \& Spiecker, 2009; Hein et al., 2009). From this aspect Thill (1975) and Hein (2004) compared crown width development with diameter increment development in sycamore maple. Kerr \& Evans (1993) considered the sycamore radial increment of $4-5 \mathrm{~mm}$ with the rotation period of 60-75 years as optimum for most of Europe. These values correspond with radial increment on PRP in the Orlické hory Mts. that was $3.0-6.4 \mathrm{~mm}(4.8 \mathrm{~mm}$ on average) at around 60 years of age.

In terms of increment, interaction between climate and radial growth of sycamore showed close relation in submontane areas. Sycamore was very sensitive on extreme weather conditions, such as very cold winters without snow or hot summers. Correlation between radial increment and temperature was stronger than precipitation, but precipitation had higher positive effect on radial growth (prevailing negative effect of winter precipitation). The climate in July and October of previous year and March of the current year had the highest effect on diameter increment. Conversely in lowlands of the Czech Republic, diameter increment of sycamore was influenced by precipitation more significantly. In the locality Klapý on former agricultural land (190 m a.s.l.) hot temperatures was limiting factor for growth, especially in April and June (Vacek et al., unpublished).

Rusanen \& Myking (2003) stated that individual trees can produce up to 170,000 seeds. On the PRP study sites, trees with the largest crowns could reach these numbers in 2015, nevertheless the number of seeds per $\mathrm{m}^{2}$ was $18-52$ (34 on average) in this richseed year compared to 2014 and 2016. Considering the seed dispersal, Neyrinck et al. (2000) concluded that there were significant differences between the soil environment of sycamore seedlings and that of European beech seedlings. Better physical and chemical properties in sycamore regeneration compared to beech were also demonstrated by Podrázský et al. (2010), because sycamore has higher-quality leaf litter fall with faster decomposition.

Although it has been reported in many studies that sycamore seedlings and saplings are very vulnerable to the competition of ground vegetation (Diaci, 2002; Modrý et al., 2004; Vendenberghe et al., 2007), on the studied PRP sycamore regeneration has survived and is prospering only in localities with ground vegetation and dead wood because on the other (open) plots it is almost completely eliminated by game.
Sycamore is an attractive tree species to hoofed game, mainly to red deer, roe deer, fallow deer and sika deer that are browsing on leaves, buds and young shoots (Gill, 1992). The browsing of juvenile sycamore individuals decreases their height growth (Kupferschmid \& Bugmann, 2008) and often results in the increased occurrence of stem forking (Harmer, 2001; Modrý et al., 2004). On study PRP sycamore regeneration was heavily damaged $(89 \%)$ by roe deer, and partly by red deer, such as in others locality in the Orlické hory Mts. (Vacek et al., 2014; Slanař et al., 2017). Great losses were caused also by brown hare there (Vacek, 2017). Schulze et al. (2014) reported that sycamore regeneration is damaged by red and roe deer to a greater extent than European beech regeneration. Similar findings were observed from stands under conversion or from stands with dominant Norway spruce where the number of juvenile sycamore individuals was low (Diaci, 2002; Nagel et al., 2015). In these cases, Mosandl \& El Kateb (1988) and Ammer (1996) recommended the control and regulation of game stocks in order to provide for sufficient density of regeneration and its prosperity. Modrý et al. (2004) stated that the high pressure of game on sycamore regeneration leads to beech dominance, which is evident also on the study area.

On the studied plots the spatial pattern of individuals of the sycamore tree layer was mostly aggregated, there was occasionally a random pattern to a distance of $15 \mathrm{~m}$. Janík et al. (2016) reported the prevailing aggregated distribution of sycamore groups in the tree layer in the Žofínský virgin forest while the regular pattern occurred there only occasionally and at distances greater than $12 \mathrm{~m}$. A distinctly positive spatial correlation at distances of 9-11 $\mathrm{m}$ and 18-19 $\mathrm{m}$ was found between individuals of the tree layer and sycamore regeneration whereas the negative correlation was not determined on any of the plots. Next these authors also stated that sycamore natural regeneration did not depend on larger stand gaps. But other studies (Marinšek \& Diaci, 2004; Nagel et al., 2010) found to the contrary.

Generally, the studies stands showed high production potential and considerable ecological value. The latter mainly with respect to structural diversity and tree species composition, where mainly Sycamore leaf litter fall contributes to the formation of high-quality humus with the good nutrient cycle (Heitz \& Rehfuess, 1999), which contributes to ecological stability and biodiversity of these ecosystems (Bell, 2009).

\section{Conclusion}

In Sudetes range system, as in most of Europe, sycamore maple is a very important tree species. Yet, the species has not been studied extensively until 
now because of its lower representation in forest stands. Our study stands originated naturally by succession, especially on abandoned agricultural lands. Those mixed stands with an abundant proportion of sycamore are characterized by their considerable production and economic value, although they received minimum silvicultural treatments in the past. However, browsing by game is a limiting factor of sycamore regeneration. Growth analyses show higher relationship with temperature, especially high sensitive to extremely cold dry winters and high summer temperatures, while precipitation is more crucial factor for growth in these submontane areas. Our results demonstrate that sycamore is a tree species with high wood production capable to spontaneously create forest stands with high ecological stability and considerable biodiversity.

\section{Acknowledgement}

This study was supported by the Ministry of Agriculture of the Czech Republic (project No. Q1330121), by the Czech University of Life Sciences Prague, Faculty of Forestry and Wood Sciences (No. IGA B03/17) and by the specific research of University of Hradec Králové, Faculty of Science.

\section{References}

Ambrazevicius V (2016) Natural regeneration of Sycamore maple in southern Sweden and Lithuania. Alnarp: SLU, Southern Swedish Forest Research Centre.

Ammer C (1996) Konkurrenz um licht-zur entwicklung der naturverjüngung im bergmischwald. Forstliche Forschungsberichte München 158: 1-198.

Barbati A, Marchetti M, Chirici G \& Corona P (2014) European forest types and forest Europe SFM indicators: Tools for monitoring progress on forest biodiversity conservation. Forest Ecology and Management 321: 145-157.

Baycheva T, Inhaizer H, Lier M, Prins K \& Wolfslehner B (2013) Implementing criteria and indicators for sustainable forest management in Europe. European Forest Institute, Joensuu.

Bell S (2009) Valuable broadleaved trees in the landscape: Valuable broadleaved forests in Europe (ed. by H Spiecker, S Hein, K Makkonen-Spiecker \& M Thies M) EFI Research-Report, European Forest Institute, European Forest Institute, Brill: Leiden, Boston, Köln, pp. 171-200.

Binggeli P (1993) The conservation value of sycamore. The Quarterly Journal of Economics 87: 143-146.
Burschel P \& Huss J (1997) Lehrbuch des waldbaus: ein leitfaden für studium und praxis. 2nd ed. Parey Verlag, Berlin.

Claessens H, Pauwels D, Thibaut A \& Rondeux J (1999) Site index curves and autecology of ash, sycamore and cherry in Wallonia (Southern Belgium). Forestry 72: 171-182.

Clark PJ \& Evans FC (1954) Distance to nearest neighbor as a measure of spatial relationship in populations. Ecology 35: 445-453.

Coote L, French LJ, Moore KM, Mitchell FJG \& Kelly DL (2012) Can plantation forests support plant species and communities of semi-natural woodland? Forest Ecology and Management 283: 8695.

Diaci J (2002) Regeneration dynamics in a Norway spruce plantation on a silver fir-beech forest site in the Slovenian Alps. Forest Ecology and Management 161: 27-38.

Dobrowolska D (1998) Structure of silver fir (Abies alba Mill.) natural regeneration in the 'Jata' reserve in Poland. Forest Ecology and Management 110: 237-247.

Ellenberg H (1996) Vegetation Mitteleuropas mit den Alpen in ökologischer, dynamischer und historischer sicht. Ulmer, Stuttgart.

Foster BC, Wang D, Keeton WS \& Ashton MS (2010) Implementing sustainable forest management using six concepts in an adaptive management framework. Journal of Sustainable Forestry 29: 79-108.

Füldner K (1995) Strukturbeschreibung von buchen-edellaubholz-mischwäldern. Dissertation Forstliche Fakultät Göttingen, Cuvillier Verlag, Göttingen.

Gill RMA (1992) A review of damage by mammals in north temperate forests: 3 . Impact on trees and forests. Forestry 65: 363-388.

Grissino-Mayer HD, Holmes RL \& Fritts HC (1992) International tree-ring data bank program library: user's manua. Laboratory of Tree-Ring Research, University of Arizona, Tuscon.

Harmer R (2001) The effect of plant competition and simulated summer browsing by deer on tree regeneration. Journal of Applied Ecology 38: 10941103.

Hein S, Collet C, Ammer C, Le Goff N, Skovsgaard JP \& Savill P (2009) A review of growth and stand dynamics of Acer pseudoplatanus L. in Europe: implications for silviculture. Forestry 82: 361-385.

Hein S (2009) Distribution of valuable broadleaved forests in Europe, Appendix B: Valuable broadleaved forests in Europe (ed. by $\mathrm{H}$ Spiecker, S Hein, K Makkonen-Spiecker \& M Thies) EFI Research-Report, European Forest Institute, pp. 251-256. 
Hein S \& Spiecker H (2009) Controlling diameter growth of Common ash, Sycamore maple and Wild cherry: Valuable broadleaved forests in Europe (H Spiecker, S Hein, K Makkonen-Spiecker \& M Thies) EFI Research-Report, European Forest Institute, pp. 103-122.

Heitz R \& Rehfuess KE (1999) Reconversion of Norway spruce (Picea abies/L./ Karst.) stands into mixed forests: effects on soil properties and nutrient $\mathrm{fl}$ uxes: Management of mixed-species forest: silviculture and economics (ed. by AFM Olsthoorn, HH Bartelink, JJ Gardiner, H Pretzsch, HJ Hekhuis \& A Franc A) IBN Scientific Contributions, pp. $46-57$.

Hemery GE, Savill PS \& Pryor SN (2005) Applications of the crown diameter-stem diameter relationship for different species of broadleaved trees. Forest Ecology and Management 215: 285-294.

Henriksen HA \& Bryndum H (1989) Zur durchforstung von bergahorn und buche in Dänemark. Allgemeine Forst- und Jagdzeitschrift 38/39: 1043-045.

Hérault B, Thoen D \& Honnay O (2004) Assessing the potential of natural woody species regeneration for the conversion of Norway spruce plantations on alluvial soils. Annals of Forest Science 61: 711-719.

Hölscher D (2004) Leaf traits and photosynthetic parameters of saplings and adult trees of co-existing species in a temperate broad-leaved forest. Basic and Applied Ecology 5: 163-172.

Jaehne S \& Dohrenbusch A (1997) Ein verfahren zur beurteilung der bestandesdiversität. Forstwissenschaftliches Centralblatt 116: 333-345.

Janík D, Adam D, Hort L, Král K, Šamonil P, Unar P \& Vrška T (2016) Breaking through beech: A three-decade rise of sycamore in old-growth European forest. Forest Ecology and Management 366: 106-117.

Joyce PM, Huss J, McCarthy R \& Pfeiffer A (1998) Growing broadleaves for Ash, Sycamore, Wild Cherry. Dublin, COFORD, National University of Ireland.

Kazda M, Salzer J, Schmid I \& Von Wrangell P (2004) Importance of mineral nutrition for photosynthesis and growth of sessile oak, Fagus sylvatica and Acer pseudoplatanus planted under Norway spruce canopy. Plant and Soil 264: 25-34.

Kerr G \& Evans J (1993) Growing broadleaves for timber. Forestry Commission Handbook 9, London.

Kjølby V (1958) Ar Naturhistorie, tilvækst og hugst: Ar (Acer pseudoplatanus L.). Dansk Skovforening, pp. 5-126.

Kölling C (2007) Klimahüllen für 27 Waldbaumarten. Allgemeine Forstzeitschrift/Der Wald 23: $1242-1245$.
Köppen W (1936) Das geographische system der klimate, handbuch der klimatologie. Gebrüder Borntraeger, Berlin.

Konôpka B \& Pajtík J (2015) Why was browsing by red deer more frequent but represented less consumed mass in young maple than in ash trees?! Journal of Forest Science 61: 431-438.

Králíček I, Vacek Z, Vacek S, Remeš J, Bulušek D, Král J, Štefančík I \& Putalová T (2017) Dynamics and structure of mountain autochthonous sprucebeech forests: impact of hilltop phenomenon, air pollutants and climate. Dendrobiology 77: 119137.

Kupferschmid AD \& Bugmann H (2008) Ungulate browsing in winter reduces the growth of Fraxinus and Acer saplings in subsequent unbrowsed years. Plant Ecology 198: 121-134.

Lindenmayer DB, Margules CR \& Botkin D (2000) Indicators of forest sustainability biodiversity: the selection of forest indicator species. Conservation Biology 14: 941-950.

Lockow KW (2004) Die erste ertragstafel für bergahorn im nordostdeutschen tiefland. Beiträge für Forstwirtschaft und Landschaftsökologie 38: 121-130.

Margalef R (1958) Information theory in ecology. General Systematics 3: 36-71.

Marinšek A \& Diaci J (2004) Development of the initial phase after wind throw in the virgin forest remnant Ravna Gora. Zbornik gozdarstva in lesarstva 73: 31-50.

Modrý M, Hubený D \& Rejšek K (2004) Differential response of naturally regenerated European shade tolerant tree species to soil type and light availability. Forest Ecology and Management 188: 185-195.

Mosandl R \& El Kateb H (1988) Die verjüngung gemischter bergwälder - praktische konsequenzen aus 10jähriger untersuchungsarbeit. Forstwissenschaftliches Centralblatt 107: 2-13.

Nagel TA, Diaci J, Jerina K, Kobal M \& Rozenbergar D (2015) Simultaneous influence of canopy decline and deer herbivory on regeneration in a conifer-broadleaf forest. Canadian Journal of Forest Research 45: 265-275.

Nagel T, Svoboda M, Rugani T \& Diaci J (2010) Gap regeneration and replacement patterns in an oldgrowth Fagus-Abies forest of Bosnia-Herzegovina. Plant Ecology 208: 307-318.

Neyrinck J, Mirtcheva S, Sioen G \& Lust N (2000) Impact of Tilia platyphyllos Scop., Fraxinus excelsior L., Acer pseudoplatanus L., Quercus robur L. and Fagus sylvatica L. on earthworm biomass and physico-chemical properties of a loamy topsoil. Forest Ecology and Management 133: 275-286.

Nunez-Regueira L, Rodriguez-Anon J \& Proupin-Castineiras J (1997) Calorific values and 
flammability of forest species in glacial, continental high mountainous and humid Atlantic zones. Bioresource Technology 61: 111-119.

Oxbrough A, Irwin S, Wilson M \& O'Halloran J (2014) Mechanisms and predictors of ecological change in managed forests: A selection of papers from the second international conference on biodiversity in forest ecosystems and landscapes. Forest Ecology and Management 321: 1-4.

Petráš R \& Pajtík J (1991) Sústava česko-slovenských objemových tabuliek drevín. Lesnický časopis 37: 49-56.

Petritan AM, von Lüpke B \& Petritan IC (2007) Effects of shade on growth and mortality of maple (Acer pseudoplatanus), ash (Fraxinus excelsior) and beech (Fagus sylvatica) saplings. Forestry 80: 397 412.

Pielou EC (1975) Ecological diversity. Wiley, New York.

Piovesan G, Di Filippo A, Alessandrini A, Biondi F \& Schirone B (2005) Structure, dynamics and dendroecology of an old-growth Fagus forest in the Apennines. Journal of Vegetation Science 16: 13-28.

Podrázský V \& Vacek S (2010) Půdy lesů a ekosystémů nad horní hranicí lesa $\mathrm{v}$ národních parcích Krkonoš. Kostelec nad Černými lesy, Lesnická práce.

Pommerening A (1997) Erwartete und beobachtete artendurchmischung am beispiel von buchen-edellaubholzbeständen. Sektion Ertragskunde im Deutschen Verband Forstlicher Forschungsanstalten, Jahrestagung 1997, Grünberg, 12. -14. Mai 1997, pp. 45-59.

Pretzsch H (2006) Wissen nutzbar machen für das management von waldökosystemen. Allgemeine Forstzeitschrift/Der Wald 61: 1158-1159.

Puettmann KJ \& Ammer C (2007) Trends in North American and European regeneration research under the ecosystem management paradigm. European Journal of Forest Research 126: 1-9.

Quitt E (1971) Klimatické oblasti Československa. Geografický ústav ČSAV, Brno.

Radzka E \& Rymuza K (2015) Multi-trait analysis of agroclimate variations during the growing season in east-central Poland (1971-2005). International Agrophysics 29: 213-219.

Ripley BD (1981) Spatial statistics. 1st ed. John Wiley \& Sons, New York.

Roček Z (1977) Příroda Orlických hor a Podorlicka. SZN, Praha.

Röhrig E \& Ulrich B (1991) Ecosystems of the world 7: temperate deciduous forests. Elsevier, London and New York.

Rusanen M \& Myking T (2003) EUFORGEN technical guidelines for genetic conservation and use for Sycamore (Acer pseudoplatanus). International Plant Genetic Resources Institute, Rome.

Schober R (1995) Ertragstafeln wichtiger baumarten bei verschiedener durchforstung. 4. Auflage. J.D. Sauerländer's Verlag, Frankfurt, Germany.

Schulze ED, Bouriaud O, Wäldchen J, Eisenhauer N, Walentowski H, Seele C, Heinze E, Pruschitzki U, Dănilă G, Marin G, Hessenmöller D, Bouriaud L \& Teodosiu M (2014) Ungulate browsing causes species loss in deciduous forests independent of community dynamics and silvicultural management in Central and Southeastern Europe. Annals of Forest Research 57: 267-288.

Schweingruber FH, Eckstein D, Serre-Bachet F \& Bräker OU (1990) Identification, presentation and interpretation of event years and pointer years in dendrochronology. Dendrochronologia 8: 8-38.

Senn J \& Suter W (2003) Ungulate browsing on silver fir (Abies alba) in the Swiss Alps: beliefs in search of supporting data. Forest Ecology and Management 181: 151-164.

Shannon CE (1948) A mathematical theory of communications. Bell System Technical Journal 27: 379-423.

Slanař J, Vacek Z, Vacek S, Bulušek D, Cukor J, Štefančík I, Bílek L \& Král J (2017) Long-term transformation of submontane spruce-beech forests in the Jizerské hory Mts.: dynamics of natural regeneration. Central European Forestry Journal 63: 213-225.

Sjöstedt J (2012) A literature study and survey of sycamore maple (Acer pseudoplatanus L.) in southern Sweden. Swedish University of Agricultural Sciences. Master Thesis no. 193, Southern Swedish Forest Research Centre, Alnarp.

Skovsgaard JP \& Jørgensen BB (2004) Beech, oak, sycamore, Norway maple and red oak on the flat heathland of mid Jutland. Dansk Skovbrugs Tidsskrift 89: 39-56.

Soulères G (1997) Les feuillus précieux-les prix des bois sur pied et leur évolution 1955-1995. Forêts de France 404: 2-8.

Spiecker H, Hansen J, Klimo E, Skovsgaard JP, Sterba H \& von Teuffel K (2004) Norway spruce conversion-options and consequences. European Institute Research Report, vol. 18. Brill, Leiden, Boston.

Spiecker H, Hein S, Makkonen-Spiecker K \& Thies M (2009) Valuable broadleaved forests in Europe. EFI Research-Report 22. European Forest Institute, Brill, Leiden, Boston, Köln.

Straigyte L \& Baliuckas V (2015) Spread intensity and invasiveness of sycamore maple (Acer pseudoplatanus L.) in Lithuanian forests. iForest 8: 693-699.

Thies M, Hein S \& Spiecker H (2009) Results of a questionnaire on management of valuable broadleaved 
forests in Europe: Valuable broadleaved forests in Europe (ed. by H Spiecker, S Hein, K Makkonen-Spiecker \& M Thies) EFI Research-Report, European Forest Institute, pp. 27-42.

Thill A (1975) Contribution ŕ l'étude du fręne, de l'érable sycomore et du merisier (Fraxinus excelsior L., Acer pseudoplatanus L., Prunus avium L.). Bulletin de la Société Royale de Forestière de Belgique 82: 1-12.

Tillisch E (2001) Æren trænger sig frem. Dan. Skovbrugs Tidssk. 86: 1-96.

Úradníček L, Maděra P, Tichá S \& Kobližek J (2001) Dřeviny České republiky. Matice lesnická, Písek.

Vacek S (2003) Mountain forests of the Czech Republic. Ministry of agriculture of the Czech Republic, Prague.

Vacek S, Simon J, Podrázský V, Baláš M, Slávik M, Turčáni M, Šrůtka P, Čížková D, Nakládal O, Malík V, Kobliha J, Remeš J, Kuneš I, Hatlapatková L, Kašíková V, Bílek L \& Kol A (2009) Zakládání a stabilizace lesních porostů na bývalých zemědělských a degradovaných půdách. Kostelec nad Černými lesy, Lesnická práce, s. r. o.

Vacek S, Hůnová I, Vacek Z, Hejcmanová P, Podrázský V, Král J, Putalová T \& Moser WK (2015) Effects of air pollution and climatic factors on Norway spruce forests in the Orlické hory Mts. (Czech Republic), 1979-2014. European Journal of Forest Research 134: 1127-1142.

Vacek S, Černý T, Vacek Z, Podrázský V, Mikeska M \& Králíček I (2017) Long-term changes in vegetation and site conditions in beech and spruce for- ests of lower mountain ranges of Central Europe. Forest Ecology and Management 398: 75-90.

Vacek Z, Vacek S, Bílek L, Král J, Remeš J, Bulušek D \& Králíček I (2014) Ungulate impact on natural regeneration in spruce-beech-fir stands in Černý důl nature reserve in the Orlické Hory mountains, case study from central Sudetes. Forests 5: 29292946.

Vacek Z (2017) Structure and dynamics of sprucebeech-fir forests in Nature Reserves of the Orlické hory Mts. in relation to ungulate game. Central European Forestry Journal 63: 23-34.

Vandenberghe C, Fréléchoux F, Moravie MA, Gadallah F \& Buttler A (2007) Short-term effects of cattle browsing on tree sapling growth in mountain wooded pastures. Plant Ecology 188: 253-264.

Walentowski H, Ewald J, Fischer A, Kölling C \& Türk W (2006) Handbuch der natürlichen Waldgesellschaften Bayerns. 2nd edn. Geobotanica Verlag, Freising.

Weber G, Rehfuess KE \& Kruetzer K (1993) Über den einfl $u ß$ naturnaher waldwirtschaft auf den chemischen bodenzustand. Allgemeine Forstzeitschrift 48: 68-71.

Weidema I \& Buchwald E (2010) NOBANIS - Invasive alien species fact sheet - Acer pseudoplatanus. Database of the European Network on Invasive Alien Species - NOBANIS.

Yamaguchi DK (1991) A simple method for cross-dating increment cores from living trees. Canadian Journal of Forest Research 21: 414-416. 